\title{
The effect of wave-induced turbulence on intertidal mudflats: Impact of boat traffic and wind
}

\author{
R. Verney ${ }^{a, b}$, J. Deloffre ${ }^{b}$, J.-C. Brun-Cottan ${ }^{c}$ and R. Lafite ${ }^{b}$ \\ a IFREMER, BP70, 29280 Plouzane, France \\ ${ }^{\mathrm{b}}$ UMR CNRS 6143 M2C, University of Rouen, 76821 Mont Saint Aignan Cedex, France \\ ${ }^{\mathrm{c}}$ UMR CNRS 6143 M2C, University of Caen, 24 Allée des Tilleuls, 14000 Caen, France \\ *: Corresponding author : $\underline{\text { romaric.verney@ifremer.fr }}$
}

\begin{abstract}
:
Semi-diurnal and fortnightly surveys were carried out to quantify the effects of wind- and navigationinduced high-energy events on bed sediments above intertidal mudflats. The mudflats are located in the upper fluvial part (Oissel mudflat) and at the mouth (Vasière Nord mudflat) of the macrotidal Seine estuary. Instantaneous flow velocities and mudflat bed elevation were measured at a high frequency and high resolution with an acoustic doppler velocimeter (ADV) and an ALTUS altimeter, respectively. Suspended particulate matter concentrations were estimated by calibrating the ADV acoustic backscattered intensity with bed sediments collected at the study sites. Turbulent bed shear stress values were estimated by the turbulent kinetic energy method, using velocity variances filtered from the wave contribution. Wave shear stress and maximum wave-current shear stress values were calculated with the wave-current interaction $(\mathrm{WCl})$ model, which is based on the bed roughness length, wave orbital velocities and the wave period $\left(T_{\mathrm{S}}\right)$. In the fluvial part of the estuary, boat passages occurred unevenly during the surveys and were characterized by long waves $\left(T_{\mathrm{S}}>50 \mathrm{~s}\right)$ induced by the drawdown effect and by short boat-waves $\left(T_{\mathrm{s}}<10 \mathrm{~s}\right)$. Boat waves generated large bottom shear stress values of $0.5 \mathrm{~N} \mathrm{~m}^{-2}$ for $2-5$ min periods and, in burst of several seconds, larger bottom shear stress values up to $1 \mathrm{~N} \mathrm{~m}^{-2}$. At the mouth of the estuary, west south-west wind events generated short waves $\left(T_{\mathrm{S}}<10 \mathrm{~s}\right)$ of $H_{\mathrm{S}}$ values ranging from 0.1 to $0.3 \mathrm{~m}$. In shallow-water environment (water depth $<1.5 \mathrm{~m}$ ), these waves produced bottom shear stress values between 1 and $2 \mathrm{~N} \mathrm{~m}^{-2}$. Wave-current shear stress values are one order of magnitude larger than the current-induced shear stress and indicate that navigation and wind are the dominant hydrodynamic forcing parameters above the two mudflats. Bed elevation and SPM concentration time series showed that these high energy events induced erosion processes of up to several centimetres. Critical erosion shear stress $\left(I_{\mathrm{ce}}\right)$ values were determined from the SPM concentration and bed elevation measurements. Rough $\tau_{\mathrm{ce}}$ values were found above $0.2 \mathrm{~N} \mathrm{~m}^{-2}$ for the Oissel mudflat and about $1 \mathrm{~N} \mathrm{~m}^{-2}$ for the Vasière Nord mudflat.
\end{abstract}

These results demonstrate the advantages of combining the measurement of instantaneous velocity and bed elevation to determine in situ the erosion and deposition processes as a function of bottom shear stress variations.

Keywords: Wind waves; Boat waves; Bottom shear stress; Bed roughness length; Bed erosion; Intertidal mudflat; Seine Estuary 
A (m) : Semi-orbital excursion

$\mathrm{C}_{\mathrm{TKE}}$ : Best fit coefficient for $\mathrm{K}-\tau_{\mathrm{TKE}}$ conversion

$\mathrm{C}_{\text {SPM }}\left(\mathrm{mg} \mathrm{l}^{-1}\right)$ : Suspended particulate matter concentration

$\mathrm{f}(\mathrm{Hz})$ : Frequency

$\mathrm{f}_{\mathrm{NL}}$ : Correction coefficient for non linear interaction between wave and current

$f_{W}$ : Wave friction factor

$\mathrm{H}_{\mathrm{S}}(\mathrm{m})$ : Significant wave height

$\mathrm{H}_{\mathrm{RMS}}$ (m): Root-mean-square wave height

h (m): Water height

$\mathrm{k}$ : Wave number

$\mathrm{K}\left(\mathrm{m}^{2} \mathrm{~s}^{-2}\right)$ : Turbulent kinetic energy

kp (km): Kilometric point, distance from Paris (kp 0 : Pont Marie)

SNR (dB): ADV signal to noise ratio

$\mathrm{T}_{\mathrm{S}}(\mathrm{s})$ : Significant wave period

$\mathrm{u}, \mathrm{v}, \mathrm{W}\left(\mathrm{m} \mathrm{s}^{-1}\right)$ : Instantaneous current velocity components following the coordinates East, North ,Up

u', v', w' (m s $\left.{ }^{-1}\right)$ : Fluctuating current velocity components

$\mathrm{u}_{\mathrm{t}}{ }^{\prime}, \mathrm{v}_{\mathrm{t}}{ }^{\prime}, \mathrm{w}_{\mathrm{t}}{ }^{\prime}\left(\mathrm{m} \mathrm{s}^{-1}\right)$ : turbulent component of the instantaneous velocity

66

$\mathrm{u}_{\mathrm{W}}{ }^{\prime}, \mathrm{v}_{\mathrm{W}}{ }^{\prime}, \mathrm{w}_{\mathrm{W}}{ }^{\prime}\left(\mathrm{m} \mathrm{s}^{-1}\right)$ : Orbital velocity component of the instantaneous velocity

$\mathrm{U}(\mathrm{z})\left(\mathrm{m} \mathrm{s}^{-1}\right)$ : Mean horizontal current velocity

68

$\mathrm{U}_{\mathrm{W}}\left(\mathrm{m} \mathrm{s}^{-1}\right)$ : Maximum orbital velocity

69

$\mathrm{u}^{*}\left(\mathrm{~m} \mathrm{~s}^{-1}\right)$ : Friction velocity

$\mathrm{z}(\mathrm{m})$ : ADV recording height above the bed

$\mathrm{z}_{0}(\mathrm{~m})$ : Bed roughness length 
73 Greek letters

74

к: Von Karman constant

$\lambda$ : ADV acoustic wave length

$\rho\left(\mathrm{kg} \mathrm{m}^{-3}\right)$ : Water density

$\rho_{\mathrm{b}}\left(\mathrm{kg} \mathrm{m}^{-3}\right)$ : Sediment bulk density

79

$\tau_{\mathrm{ce}}\left(\mathrm{N} \mathrm{m}^{-2}\right)$ : Critical erosion shear stress

80

$\tau_{\text {TKE }}\left(\mathrm{N} \mathrm{m}^{-2}\right)$ : Turbulent kinetic energy shear stress

81

$\tau_{\mathrm{W}}\left(\mathrm{N} \mathrm{m}^{-2}\right)$ : Maximum wave shear stress

82

$\tau_{\mathrm{m}}\left(\mathrm{N} \mathrm{m}^{-2}\right)$ : Mean bed shear stress integrating non linear wave-current interactions

$83 \tau_{\mathrm{WC}}\left(\mathrm{N} \mathrm{m}^{-2}\right)$ : Maximum wave-current shear stress

$84 \tau_{\mathrm{W}-\mathrm{sW}}\left(\mathrm{N} \mathrm{m}^{-2}\right)$ : Wave shear stress for short-period boat-induced waves

$85 \tau_{\mathrm{W}-\mathrm{LW}}\left(\mathrm{N} \mathrm{m}^{-2}\right)$ : Wave shear stress for long-period boat-induced waves

$86 \tau_{\mathrm{W}-\mathrm{SW}+\mathrm{LW}}\left(\mathrm{N} \mathrm{m}^{-2}\right)$ : Wave shear stress for boat-induced long waves and short waves

$87 \tau_{\mathrm{C}}\left(\mathrm{N} \mathrm{m}^{-2}\right):$ Current shear stress

$88 \quad v\left(\mathrm{~m}^{2} \mathrm{~s}^{-1}\right)$ : Kinematic viscosity of water

89 


\section{Introduction}

Estuarine intertidal mudflats, which store fine-grained sediment, represent key areas for the investigation of sediment transport dynamics and estuarine water quality management. When suspended particulate matter (SPM) settles, contaminants associated with it are deposited on estuarine intertidal mudflats, which thus become the main areas of contaminants accumulation. Previous studies have demonstrated that intertidal mudflats are subjected to successive periods of erosion and sedimentation which are controlled by sediment supply and hydrodynamic forcing parameters such as tides, fluvial discharge and wind (Dyer, 1994; Allen and Duffy, 1998; Uncles et al., 1998; O'Brien et al., 2000). Therefore, the storage of fine sediment by intertidal mudflats may be temporary, as the mudflats are subjected to erosion events of variable intensity and duration, from one millimetre per day to several centimetres in a few minutes (Deloffre et al., 2005). When a major erosion event occurs, the large amount of reworked sediments and the particle-associated contaminants released into the water column increase the risk of localized pollution (Cundy et al., 2005), especially during periods when fluvial discharge is low and there therefore is little dilution.

Erosion and resuspension processes occur when the bottom shear stress exceeds a critical threshold value (Mitchener and Torfs, 1996; Black and Paterson, 1997). Extending our knowledge of the erosion processes requires both accurate measurements of the hydrodynamic features near the bottom and a good estimation of the properties of the surface sediment. Recent improvements in acoustic devices allow accurate high frequency and 3D current velocity measurements and thus provide reliable and consistent shear stress measurements (Kawanisi and Yokosi, 1997; Voulgaris and Trowbridge, 1998; Talke and Stacey, 2003; Voulgaris and Meyers, 2004). A recent study carried out in the macrotidal Seine estuary focused on the tidal-induced bottom shear stress variability (Verney et al., 2006): the results demonstrated that tidal-induced shear stress measured at different location in the macrotidal Seine estuary exceeded the calculated erosion threshold only during short high energy events (HEEs). In estuarine areas, HEEs may be caused by waves generated by boat traffic and wind, which increase the bottom shear stress (Grant and Madsen, 1979; Soulsby et al., 1993; Parchure et al., 2001). 
The objective of this study is to focus on the HEEs observed on several intertidal mudflats in a macrotidal estuary to identify and quantify the hydrodynamic factors causing the events, and to investigate the impacts of HEEs on the mudflat dynamics. This study introduces a new approach for determining the relationship between hydrodynamic parameters and mudflat erosion processes: the coupling of accurate near-bed hydrodynamic measurements with bed elevation measurements.

\section{Field site}

Before reaching the turbidity maximum zone, the SPM entering into the macrotidal Seine estuary is temporarily trapped in several fine-sediment storage areas sheltered from the strongest tidal-induced hydrodynamics conditions (Fig. 1) (Guezennec et al., 1999; Lesourd et al., 2003; Deloffre et al., 2005). Hydrodynamic conditions in the Seine Estuary are controlled by the semi-diurnal tidal cycle and are modulated seasonally by fluvial discharge (Guezennec et al., 1999). During the highest spring tides, the tidal range at the mouth of the estuary ( $\mathrm{kp} \mathrm{360)}$ is up to $7 \mathrm{~m}$ and decreases upstream to $2 \mathrm{~m}$ at the upper limit of the estuary (kp 202). During periods of low fluvial discharge, the estuary is divided into two hydrodynamic compartments: a flood-dominated compartment downstream from kp 300 (Le Trait) and an ebb-dominated compartment upstream from kp 300 (Verney et al., 2006). The influence of wind on hydrodynamic features, i.e. wind waves and swell, is observed only at the estuary mouth when the wind is from the west-south-west (Le Hir et al., 2000; Silva Jacinto, 2002).

Over the last century, the regional authorities have put an emphasis on facilitating economic exchanges and in particular on encouraging sea-vessel traffic in the Seine estuary from its mouth to the Port of Rouen (kp 245) (Lafite and Romana, 2001; Lesourd et al., 2001). This has resulted in the construction of embankments and in heavy dredging activities to keep the main navigation channel operational for sea vessels downstream from Rouen. Boat traffic within the Seine estuary is divided in two sectors: upstream from Rouen the traffic consists exclusively of barges, which transport 3.5Mt annually, whereas downstream from Rouen both barges and sea-going vessels travel the estuary, with 
more than 3,400 sea-vessels sailing seaward (Data from the Port Authorities of Rouen). Such a high amount of boat traffic has the potential to contribute to local changes in hydrodynamic conditions.

For this study, two sites, representing the fluvial and marine parts of the estuary, were investigated: the Oissel mudflat (kp 230) and the Vasière Nord mudflat (kp 355) (Fig 1). The sites were chosen on the basis of recent work on the Seine estuary (Guezennec et al., 1999; Lesourd et al., 2003; Deloffre et al., 2005; Deloffre et al., In press; Verney et al., 2006). The Oissel mudflat is one of the largest intertidal storage areas of fine sediment in the fluvial part of the estuary, with a surface area of $9500 \mathrm{~m}^{2}$. A twoyear high frequency survey of the bed elevation indicates that muddy sediments settle during high river flow, with deposition rates up to $7.5 \mathrm{~mm} \mathrm{~d}^{-1}$, and net deposits of 5 to $8.5 \mathrm{~cm}$ per episode depending on the flux of suspended solids discharging at Poses (the upstream limit of the estuary). The bed sediments are a mixture of sand and mud, and are characterised by modes of 20 and $200 \mu \mathrm{m}$ (Deloffre et al., 2005). During periods of low discharge, the previously-deposited material is eroded continuously at the rate of $0.75 \mathrm{~mm} \mathrm{~d}^{-1}$ and transported downstream. However, significant erosion events of several centimetres are occasionally observed. Hydrodynamic surveys during periods of low discharge have demonstrated that low tidal-induced bottom shear stress is lower than $0.2 \mathrm{~N} \mathrm{~m}^{-2}$ and thus not sufficient to explain the large erosion events, yet several HEEs that generated bottom shear stress larger than $1 \mathrm{~N} \mathrm{~m}^{-2}$ were observed (Verney et al., 2006).

The Vasière Nord mudflat, the largest mudflat in the estuary $\left(3.2 \mathrm{~km}^{2}\right.$, (Lesourd et al., 2003)), and is located in the northern part of the estuary mouth. Here, unlike the Oissel mudflat, the annual high frequency survey shows that deposition occurs in bursts during periods of low fluvial discharge, and is closely related to the highest spring tides and the presence of the turbidity maximum zone in the estuary mouth (Deloffre et al., In press). These deposits are dominated by fine sediments $(<50 \mu \mathrm{m})$, which represent 70 to $90 \%$ of the material (Lesourd, 2000). As in the upstream fluvial mudflat, HHEs of several centimetres are observed, mostly after deposition. ADV current velocity measurements in spring and neap tide conditions have revealed low tidal-induced bottom shear stress values, except during the rising flood period of the highest spring tides (Verney et al., 2006). The sampling station 
above the Vasière Nord mudflat is located at mid-cross-section and $6.6 \mathrm{~m}$ above the reference sea level.

\section{Materials and methods}

In order to accurately identify HEEs, sedimentary and hydrodynamic parameters were monitored with high frequency devices over tidal cycles. In addition, fortnightly cycle surveys were carried out to investigate the mudflat response to HEEs. All surveys were carried out during periods of low fluvial discharge.

\subsection{Bed-elevation measurements: the ALTUS altimeter}

The ALTUS altimeter is an autonomous $2 \mathrm{MHz}$ acoustic transducer coupled with a pressure sensor (Bassoullet et al., 2000). This device allows long term monitoring (Deloffre et al., 2005; Deloffre et al., In press), but is also suitable for high-frequency surveys (sampling frequency up to $1 \mathrm{~Hz}$ ) with a data storage capacity of several weeks. The ALTUS provides bed elevation and water level measurements with resolution of $0.2 \mathrm{~mm}$ and $20 \mathrm{~mm}$ respectively. For this study, the transducer was positioned $20 \mathrm{~cm}$ above the bed, with a sampling frequency of one measurement every three minutes.

\subsection{Hydrodynamic characteristics: ADV measurements}

Stations were instrumented with a $6 \mathrm{MHz}$ Nortek Vector Acoustic Doppler Velocimeter during periods of low fluvial discharge $\left(<400 \mathrm{~m}^{3} \mathrm{~s}^{-1}\right)$. The apparatus was fixed on a rigid aluminium frame, which was directed perpendicular to the main channel axis to minimize frame-induced noise. This setup has been found to be particularly suitable for turbulent intensity determinations (Kawanisi and Yokosi, 1997; Talke and Stacey, 2003; Voulgaris and Meyers, 2004). ADV measurements give access to the three directional components of the current velocity, $7 \mathrm{~cm}$ above the bed, and to the water level variations, with a pressure sensor located $45 \mathrm{~cm}$ above the bed. Velocity measurements were recorded 
in the East/North/Up coordinates, automatically compensating for any movement of the instrument using data provided by the ADV internal compass. This minimizes errors due to ADV misalignment with the vertical. For each tidal survey, the ADV ran continuously at the sampling frequency of $32 \mathrm{~Hz}$. For semi-lunar surveys, the ADV collected measurements at $2 \mathrm{~Hz}$ for $180 \mathrm{~s}$ bursts, every 13 min. Mean current velocity and bottom shear stress were obtained by averaging instantaneous and fluctuating components of the flow over the burst duration.

\subsubsection{Calculation of the bottom shear stress}

Various methods are presented in the literature for the calculation of bottom shear stress values from measured instantaneous current velocities : the Logarithmic velocity Profile (LP) method (Fugate and Friedrichs, 2002; Simpson et al., 2005), the Turbulent Kinetic Energy (TKE) method (Soulsby, 1983; Williams et al., 1999; Talke and Stacey, 2003), the covariance (COV) method (Kim et al., 2000; Voulgaris and Meyers, 2004) and the Inertial Dissipation (ID) method (Huntley, 1988; Kim et al., 2000; Trembanis et al., 2004). The operational limitations for applying these methods in estuarine environments have been discussed by various authors (Soulsby et al., 1993; Kim et al., 2000; Hutnance et al., 2002). HEEs observed in the Seine estuary (Verney et al., 2006) are assumed to be induced by wave events. Therefore, neither the LP nor the COV methods can be used, as the LP method is based on time-averaged flow velocity and the COV method cannot separate tidal- and waveinduced fluctuations.

The method best suited to the investigation of wave-current shear interactions is the TKE method, as a spectral analysis of the instantaneous velocity provides both turbulent and wave characteristics (Soulsby and Humphery, 1990). This method is based on the separation of the wave-induced (u' ${ }_{w}, v^{\prime}{ }_{w}$, $\mathrm{w}_{\mathrm{w}}{ }_{\mathrm{w}}$ ) and turbulence-induced $\left(\mathrm{u}_{\mathrm{t}}, \mathrm{v}_{\mathrm{t}}, \mathrm{w}_{\mathrm{t}}{ }_{\mathrm{t}}\right.$ ) variances of each fluctuating velocity components $\mathrm{u}^{\prime}, \mathrm{v}^{\prime}$ and w'. During wave events, the energy spectrum consists of the superposition of the conventional turbulent spectrum featured by the Kolmogorov $-5 / 3$ roll off in the inertial subrange and a typical wave spectrum, identified as a peak of energy in the wave frequency range (typically between 1 and $0.1 \mathrm{~Hz}$ 
for wind waves). According to Soulsby and Humphery (1990), the energy spectrum is split in two parts at the base of the wave peak. This method is performed automatically on the full $\mathrm{u}, \mathrm{v}$ and $\mathrm{w}$ dataset where, according to the Kolmogorov theory, the separation line corresponds to an interpolation of the $-5 / 3$ slope (in log space), with a reference point at $\mathrm{f}=0.1 \mathrm{~Hz}$ (outside the wave frequency range). The area below the interpolation line therefore corresponds to the turbulent kinetic energy of the velocity component considered (respectively $\mathrm{u}^{, 2}, \mathrm{v}^{, 2}$ or $\mathrm{w}^{, 2}$ ), and the area above the line to the wave variance contained in the fluctuating part of the velocity component.

The TKE shear stress $\left(\tau_{\mathrm{TKE}}\right)$ is determined from the turbulent kinetic energy $\mathrm{K}$ :

$$
\tau_{\mathrm{TKE}}=\rho \mathrm{C}_{\mathrm{TKE}} \mathrm{K}=0.5 \rho \mathrm{C}_{\mathrm{TKE}}\left(\overline{\mathrm{u}_{\mathrm{t}}{ }^{2}}+\overline{\mathrm{v}_{\mathrm{t}}{ }^{2}}+\overline{\mathrm{w}_{\mathrm{t}}{ }^{2}}\right)
$$

Various $\mathrm{C}_{\mathrm{TKE}}$ values are proposed in the literature for different estuaries, ranging from 0.18 to 0.21 (Soulsby, 1983; Kim et al., 2000; Talke and Stacey, 2003). For the Seine estuary, Verney et al. (2006) found $\mathrm{C}_{\mathrm{TKE}}=0.19$ to be the best-fit constant for the tidal-induced shear stress on intertidal mudflats. $\tau_{\mathrm{TKE}}$ is the best estimation of the bottom shear stress attributable to current in the presence of waves (Williams et al., 1999).

\subsubsection{Wave shear stress}

The significant wave height $\left(\mathrm{H}_{\mathrm{S}}\right)$, root-mean-square wave height $\left(\mathrm{H}_{\mathrm{RMS}}\right)$ and significant wave period $\left(T_{S}\right)$ are calculated from the water level (h) time series over a 1 min burst. Significant wave orbital velocity $\mathrm{U}_{\mathrm{W}}$ is calculated from the wave variances ( $\mathrm{u}_{\mathrm{W}}$ ' ans $\mathrm{v}_{\mathrm{W}}$ ') deduced from the turbulent spectrum analysis, such as (Myrhaug et al., 1998):

$$
\mathrm{UW}=2 * \sqrt{\mathrm{u}_{\mathrm{w}}^{\prime 2}+\mathrm{v}_{\mathrm{w}}^{\prime 2}}
$$

The wave shear stress $\tau_{\mathrm{w}}$ is given by:

$$
\tau_{\mathrm{W}}=1 / 2 * \rho^{*} \mathrm{f}_{\mathrm{W}} * \mathrm{U}_{\mathrm{W}}^{2}
$$

where $f_{w}$ is the wave friction factor, which depends on the turbulent characteristics of the flow. In this study flow is turbulent, and the friction factor is obtained from the relation (Soulsby, 1997): 
where $A$ is the semi-orbital excursion : $A=U_{W} T_{S} / 2 \pi$ and $z_{0}$ is the bed roughness length.

\subsubsection{Wave-current shear stress}

Waves and current both contribute to the bottom shear stress; various models have been developed to determine the combined wave-current shear stress (Grant and Madsen, 1979; Fredsoe, 1984). The method used in this study refers to the parametric Wave-Current Interaction (WCI) model proposed by Soulsby (1995). The equations used are based on theories previously developed and fitted to field and tank experiments. Soulsby introduced a correction coefficient $\mathrm{f}_{\mathrm{NL}}$ that takes into account the non-linear interaction between the waves and the current in the mean bed shear stress:

$$
\mathrm{f}_{\mathrm{NL}}=1.2 *\left(\tau_{\mathrm{w}} /\left(\tau_{\mathrm{w}}+\tau_{\mathrm{C}}\right)\right)^{3.2}
$$

The mean bed shear stress $\tau_{\mathrm{m}}$ is:

$$
\tau_{\mathrm{m}}=\tau_{\mathrm{C}}\left(1+\mathrm{f}_{\mathrm{NL}}\right)
$$

In the present study, wave-current interaction is incorporated into the $\tau_{\mathrm{TKE}}$ calculations, and therefore $\tau_{\mathrm{m}}$ is equal to $\tau_{\mathrm{TKE}}$. Given that $\Psi$ is the angle between the waves and the current, the total wave-current bed shear stress becomes:

$$
\tau_{\mathrm{WC}}=\sqrt{\left(\tau_{\mathrm{TKE}}+\tau_{\mathrm{W}} * \cos (\Psi)\right)^{2}+\left(\tau_{\mathrm{W}} * \sin (\Psi)\right)^{2}}
$$

\subsection{Bed roughness calculation}

Bed roughness length is a key parameter that must be determined when calculating wave shear stress. At the tidal scale, however, bed roughness length varies rapidly, as it is a function of sediment grainsize distribution, bedforms present, and suspended sediment concentration (Collins et al., 1998; Trembanis et al., 2004; Voulgaris and Meyers, 2004). Moreover, in the presence of waves, the bed roughness length is greatly affected by the increase in eddy viscosity within the wave boundary layer (Grant and Madsen, 1979; Soulsby and Humphery, 1990) and no longer corresponds to the physical 
bed roughness used in the WCI method to calculate wave-current shear stress. Therefore, the bed roughness length is calculated outside wave events from the drag coefficient $C_{d}(z)$ for each site at the tidal scale, and assuming the development of a logarithmic velocity profile (Soulsby and Humphery, 1990):

$$
\begin{aligned}
& \mathrm{u}^{* 2}=\mathrm{C}_{\mathrm{d}}(\mathrm{z}) * \mathrm{U}(\mathrm{z})^{2} \\
& \frac{\mathrm{U}(\mathrm{z})}{\mathrm{u}}=\frac{1}{\kappa} \log \left(\frac{\mathrm{z}}{\mathrm{z}_{0}}\right)
\end{aligned}
$$

where $\mathrm{u}^{*}$ is the friction velocity calculated from $\tau_{\mathrm{TKE}}$ such that:

$$
\mathrm{u}^{*}=\sqrt{\frac{\tau_{\mathrm{C}}}{\rho}}
$$

and

$$
\mathrm{z}_{0}=\mathrm{z} * \exp \left(-\frac{\kappa}{\sqrt{\mathrm{C}_{\mathrm{d}}(\mathrm{z})}}\right)
$$

In addition to current measurements, acoustic Doppler devices (ADCPs or ADVs) provide backscattered acoustic amplitudes and signal to noise ratios (SNR) for measurement validation. Calibrating the backscattered acoustic intensity with SPM concentrations is complex, but provides key information on sediment transport features, i.e. hydrodynamic and suspended sediment characteristics at high frequency (Kawanisi and Yokosi, 1997; Voulgaris and Meyers, 2004). The main difficulty is that the backscattered acoustic intensity depends on the SPM concentration, grain-size distribution and composition in the volume sampled. The optimal dynamical response of the ADV backscattered acoustic intensity is given for particle sizes $D_{\text {opt }}$ where $D_{\text {opt }} * \lambda / 2=1$ and $\lambda$ is the ADV unity for coarser particles, assuming that the entire emitted signal is returned to the transducers. For a $6 \mathrm{MHz} \mathrm{ADV}$ such as the one used for this study, the operational size range is estimated to be between $10 \mu \mathrm{m}$ and $200 \mu \mathrm{m}$, with the optimal size calculated to be $80 \mu \mathrm{m}$, similar to the mode value of the grain-size 
distribution of the muddy material present in the estuary (Lesourd, 2000). This validates the use of the ADV backscatter as an appropriate proxy for estimating SPM concentration.

In parallel to physical acoustic theories (Thorne and Hanes, 2002), Voulgaris and Meyers (2004) proposed empirical calibrations to convert backscatter signal to SPM concentration. For this study, calibration experiments were carried out in the laboratory using surface sediments collected at the two sampling stations (Fig. 2). The calibration experiment is based on a classical calibration set-up, i.e., the ADV is immersed in a tank that is homogeneously filled step by step with surface sediments to increase the SPM concentration ( $\left.\mathrm{C}_{\mathrm{SPM}}\right)$. The ADV acoustic backscattered intensity is recorded for $30 \mathrm{~s}$ and a water sample is collected to determine the weighted $\mathrm{C}_{\mathrm{SPM}}$. The burst-averaged SNR values are used to quantify the backscattered acoustic intensity, and then compared with the measured $\mathrm{C}_{\mathrm{SPM}}$ in the tank for all sediments (Fig. 2). $\log (\mathrm{SNR})$ is linearly correlated with $\log \left(\mathrm{C}_{\mathrm{SPM}}\right)$ for both sites :

$$
\log \left(\mathrm{C}_{\mathrm{SPM}}\right)=-26.48+15.03 * \log (\mathrm{SNR})\left(\text { Fig. } 2 \text { - Vasière Nord [1]) }\left(\mathrm{R}^{2}=0.84\right)\right.
$$

$$
\log \left(\mathrm{C}_{\mathrm{SPM}}\right)=-28.02+15.91 * \log (\mathrm{SNR})(\text { Fig. } 2-\text { Oissel [2] })\left(\mathrm{R}^{2}=0.98\right)
$$

For these two calibration sets, the operational concentration ranges from 10 to $5000 \mathrm{mg} \mathrm{l}^{-1}$. At lower concentrations, the backscattered intensity is highly variable and the calibration curve does not show a consistent pattern. For $\mathrm{C}_{\mathrm{SPM}}$ higher than $5000 \mathrm{mg} \mathrm{l}^{-1}$, the ADV response no longer changes with increasing $\mathrm{C}_{\mathrm{SPM}}$. However, in practice this upper limit is never reached as $\mathrm{C}_{\mathrm{SPM}}$ rarely exceeds 3000 $\mathrm{mg} \mathrm{l}^{-1}$ in the Seine estuary (Lesourd, 2000; Deloffre et al., 2005).

This empirical method for ADV-SPM calibration was used by Voulgaris and Meyers (2004) (Fig. 2). However, it should be noted that these authors used a $10 \mathrm{MHz}$ Sontek ADV that is more sensitive to finer particles and lower $\mathrm{C}_{\mathrm{SPM}}$. This explains the difference between their calibration equation and that presented here. 


\section{Results}

\subsection{High Energy Events and forcing parameters}

\subsubsection{The estuary mouth: the wind influence}

A typical W-SW wind event occurred on May 5, 2004, with an average wind speed of $8 \mathrm{~m} \mathrm{~s}^{-1}$ and gusts of $10 \mathrm{~m} \mathrm{~s}^{-1}$ (Fig. 3). W-SW wind events of similar intensities are known to increase wave action in the estuary mouth (Silva Jacinto, 2002). The sampling station is located in the middle of the largest mudflat in the estuary, at the height of $6.6 \mathrm{~m}$ above reference sea level, thus water heights above the station rarely exceed $1 \mathrm{~m}$ during neap tide conditions. The water level fluctuations measured by the ADV and filtered from the tidal amplitude are shown in Fig. 3a. Waves are observed continuously during the tidal cycle, with significant wave periods varying from 3 to $8 \mathrm{~s}$ and significant wave heights ranging from 0.1 to $0.35 \mathrm{~m}$ (Fig. 3b). Waves were present continuously during this survey, so the bed roughness length was not calculated. Instead, the bed roughness calculated for the same site during the fortnightly cycle was used $\left(\mathrm{z}_{0}=0.37 \mathrm{~mm}\right)$ as well as the bed roughness lengths given by Soulsby (1997) for mud and muddy/sandy sediment (i.e., 0.2 and $0.7 \mathrm{~mm}$ respectively) to investigate the variability of the results.

The wave-current shear stress fluctuations are shown in Fig 3c and compared to the TKE shear stress. During the survey, $\tau_{\mathrm{WC}}$ values were twice to one order of magnitude higher than $\tau_{\mathrm{TKE}}$, with characteristic values ranging from 0.6 to $4 \mathrm{~N} \mathrm{~m}^{-2}$ and 0.1 to $1 \mathrm{~N} \mathrm{~m}^{-2}$, respectively, for $\tau_{\mathrm{WC}}$ and $\tau_{\mathrm{TKE}}$. This confirms that wind-waves are the dominant forcing parameter at the estuary mouth. The largest waves $(>0.2 \mathrm{~m})$ are associated with $\tau_{\mathrm{WC}}$ values above $1 \mathrm{~N} \mathrm{~m}^{-2}$. Comparing $\tau_{\mathrm{WC}}$ values obtained for the different bed roughness values (Fig. 3c - shadow area) demonstrates high sensitivity of the $z_{0}$ calculation: estimating $\tau_{\mathrm{wC}}$ with $\mathrm{z}_{0}=0.2 \mathrm{~mm}$ or $0.7 \mathrm{~mm}$ results in discrepancies of up to $100 \%$ compared with $\tau_{\text {WC }}$ calculated with $\mathrm{z}_{0}=0.37 \mathrm{~mm}$. 
Representative water level recordings from the Oissel mudflat are shown in Fig. 4a. Examination of the water elevation time-series reveals the passage of at least five boats. These passages are identified by the boat-generated wave packets with amplitudes up to $0.16 \mathrm{~m}$.

A ship passage is examined in detail in Fig. 4b and Fig. 4c; the figures show typical vessel-generated water-level and current-velocity variations. These boat-induced variations affect the local hydrodynamics and are characterised by one long wave followed by short wave packets as reported in previous studies (Schoellhamer, 1996; Fagerburg and Pratt, 1998; Parchure et al., 2001).

Long waves are caused by the drawdown effect, which is defined as an abrupt diminution of the water level caused by the displacement of the boat. The occurrence and amplitude of the drawdowns are controlled by the width of the channel, the local water depth and some boat-related features, such as the shape of the hull and the boat speed, e.g., the narrower the width, the larger the drawdown (Schoellhamer, 1996; Fagerburg and Pratt, 1998). Here, the drawdown shows a wave period of $50 \mathrm{~s}$ and an amplitude of $0.06 \mathrm{~m}$. The wave is reflected several times by the river banks and its amplitude decays with time. The drawdown substantially affects the local current velocities, causing horizontal velocity variations of $0.2 \mathrm{~m} \mathrm{~s}^{-1}$ (Fig. 4 c). This type of long wave is observed before the arrival of short wave packets. In Fig. 4b, the boat-generated short waves have a period of $3 \mathrm{~s}$, the first and largest wave height is $0.1 \mathrm{~m}$ and following wave heights decrease with time. Wave packets are observed several times as a result of reflections on embankments. The boat passage affects the mudflat for 2- to 5-min periods, and induces high flow velocity fluctuations: the largest fluctuation amplitude is $0.3 \mathrm{~m} \mathrm{~s}^{-}$ ${ }^{1}$ and then decreases with time (Fig. 4 c).

Waves generated by barges or vessels contribute to the bottom shear stress. This contribution can be estimated using the WCI model detailed in section 3.2.3. The bed roughness length for the Oissel 
mudflat was estimated by Verney et al. (2006) to be $0.3 \mathrm{~mm}$, from the calculation of the drag coefficient obtained by comparing mean current velocity $U$ and friction velocity $\mathrm{u}^{*}$ in the absence of waves. Wave height measurements revealed that the boat-generated waves are mono- or sometimes bimodal. As described in the previous section, the WCI model is applied for waves characterised by a single period and a single height. Short and long waves were examined separately to estimate the shear stress contribution of each type of wave and to determine the total boat-induced bottom shear stress. Long and short waves were filtered by band-pass filters from the spectral analysis of the raw-water level signal, with long and short wave frequencies assumed to range from $0.002 \mathrm{~Hz}$ to $0.1 \mathrm{~Hz}$, and 0.1 $\mathrm{Hz}$ to $1 \mathrm{~Hz}$, respectively. Fig. 5 focuses on a typical time series corresponding to Fig. 4b and details the procedure applied to calculate $\tau_{\mathrm{wc}}$. Once extracted from the raw signal (Fig. $5 \mathrm{a}, \mathrm{b}$ and c), the long and short wave signals are processed to calculate their respective wave periods and significant wave heights. Long wave properties are calculated over a 1 min period. However, this calculation period is too long to represent accurately the rapidly fluctuating short waves, and so the significant wave heights, periods and orbital velocities for short waves were calculated over an $8 \mathrm{~s}$ burst period. Short effect, and $\tau_{\mathrm{W} \text {-sw }}$ increases when short waves arrive, with a maximum value of $1 \mathrm{~N} \mathrm{~m}^{-2}$. Low amplitude

413 short waves are observed during the drawdown period, generating a wave shear stress of $0.08 \mathrm{~N} \mathrm{~m}^{-2}$, lower than the $\tau_{\mathrm{W} \text {-LW }}$ value. $\tau_{\mathrm{W} \text {-SW }}$ and $\tau_{\mathrm{W} \text {-LW }}$ then are summed to obtain the overall wave shear stress 
(Fig. 5e). $\tau_{\mathrm{TKE}}$ is one order of magnitude lower than $\tau_{\mathrm{WC}}$ and non-linear wave effects on $\tau_{\mathrm{TKE}}$ are observed. This procedure is extended to the entire dataset (Fig. 6). During the tidal cycle, $\tau_{\mathrm{TKE}}$ is well correlated with the current velocity (Fig. 6: from $03 \mathrm{~h} 00$ to $06 \mathrm{~h} 00$ ).

All boat passages generate bottom shear stress with $\tau_{\mathrm{WC}}$ values above $0.1 \mathrm{~N} \mathrm{~m}^{-2}$ and up to $2 \mathrm{~N} \mathrm{~m}^{-2}$. The boat traffic in the Seine estuary is dense, and occasionally boats must either follow each other closely or pass each other with very little clearance in the narrow channel. This results in longer duration HEEs, characterised by a succession of multiple wave packets, which can combine with each other and generate larger waves and thus greater bottom shear stress (Fig. 6 - from $00 \mathrm{~h} 40$ to 01h20). In this case, the turbulent flow relaxes slightly and does not reach a steady state until more than 20 min after the last barge passage.

\subsection{Impact of the HEEs on the dynamics of the intertidal mudflats of the Seine estuary}

The factors controlling the variability of the bottom shear stress intensity are identified by tidal surveys as the tidal currents (Verney et al., 2006), the W-SW wind events (at the mouth of the Seine estuary), and the passage of boats and barges (in the fluvial part of the estuary). Based on these studies, surveys were carried out in the fluvial part of the estuary and at the mouth of the estuary to monitor hydrodynamic and sedimentary processes during a semi-lunar cycle. The objective of this work is to investigate the impact of HEEs on the mudflat dynamics, and in particular the erosion and resuspension processes affecting the surface sediment.

\subsubsection{Wind impact on mudflat behaviour}

The Vasière Nord survey was carried out in spring tide conditions, which are reported as being favourable for sediment accretion above the mudflat (Deloffre et al., In press). The variations of the 
bed elevation of the Vasière Nord mudflat are compared to the time series of $\tau_{\mathrm{WC}}$, SPM concentration, water surface elevation, and wind and wave conditions (Fig. 7).

Throughout the survey, the water level above the mudflat never exceeded $1.5 \mathrm{~m}$ (Fig. 7 a). Wind speed above $10 \mathrm{~m} \mathrm{~s}^{-1}$ are observed unevenly; they generate wind waves with an average wave height of 0.15 $\mathrm{m}$ and wave periods ranging from 2 to $10 \mathrm{~s}$. Waves are always observed above the mudflat and the lowest wave heights are less than $0.1 \mathrm{~m}$ and correlated with wind speeds below $5 \mathrm{~m} \mathrm{~s}^{-1}$ (Fig. 7 b). Periods of large amplitude waves, above $0.2 \mathrm{~m}$, are observed in bursts.

450

The weakest wave event occurred during VN1, and this period there was chosen to calculate a $\mathrm{z}_{0}$ value (wave heights $>0.1 \mathrm{~m}$ excluded), and estimated to be $0.37 \mathrm{~mm}$. The combination of low water heights and large wave amplitudes induces strong bottom shear stresses. Periods of wind-wave heights above $0.15 \mathrm{~m}$ are reported as HEEs and correspond to bottom shear stress values higher than $0.5 \mathrm{~N} \mathrm{~m}^{-2}$ for periods lasting from the hour to the tidal scale (Fig. 7 c and d). The largest HEE (VN2) is correlated with a SW wind event of $13 \mathrm{~m} \mathrm{~s}^{-1}$, generating wave heights up to $0.3 \mathrm{~m}$ and $\tau_{\mathrm{WC}}$ of $2 \mathrm{~N} \mathrm{~m}^{-2}$. Calm periods are associated with bottom shear stress values below $0.5 \mathrm{~N} \mathrm{~m}^{-2}$.

The Vasière Nord mudflat underwent several periods of sedimentation and resuspension/erosion (Fig. 7f). A typical sedimentation/resuspension pattern is observed, characterized by a new deposit during the flood period: VN1: $+10 \mathrm{~mm}, \mathrm{VN} 3:+3 \mathrm{~mm}$; VN4: $+5 \mathrm{~mm}$. Deposition events are correlated with the weakest hydrodynamic conditions, i.e. $\tau_{\mathrm{wC}}<0.8 \mathrm{~N} \mathrm{~m}^{-2}$ and wave heights below $0.15 \mathrm{~m}$. Resuspension and erosion periods are observed during HEEs characterised by $\tau_{\mathrm{wC}}$ values greater than $1 \mathrm{~N} \mathrm{~m}^{-2}$, induced by wind-wave heights above $0.15 \mathrm{~m}$. These HEEs partly or entirely remove the previously deposited sediment (Fig. 7f): VN1: $-2 \mathrm{~mm}$; VN2: $-7 \mathrm{~mm}$; VN3: $-5 \mathrm{~mm}$; VN4: $-2.5 \mathrm{~mm}$, VN5: $-7 \mathrm{~mm}$, VN6: $-2 \mathrm{~mm}$. This material is re-enters the water column, as demonstrated by the monitoring of $\mathrm{C}_{\mathrm{SPM}}$ : every resuspension or erosion event is correlated with high $\mathrm{C}_{\mathrm{SPM}}$ values above 100 $\mathrm{mg} \mathrm{l}^{-1}$, and occasionally as high as to $1500 \mathrm{mg} \mathrm{l}^{-1}$ (Fig. 7e) 
At the scale of the survey, the total amount of deposited sediments is removed, and the net budget of

471

472

473

474

475

476

477

478

479

480

481

482

483

484

the erosion/sedimentation periods shows is an erosion of the bed of $5 \mathrm{~mm}$. This erosion was confirmed by field observation at the end of the survey: the surface of the mudflat was rippled, made up of hard sandy-mud, and hard-mud pebbles were scattered over the mudflat as a consequence of strong hydrodynamic conditions and erosion at the edge of the mudflat.

\subsubsection{Boat impact on mudflat behaviour}

The results of the bed roughness length calculation during the survey are shown in Fig. 8. They reveal a variability of $30 \%$ around a mean value of $0.1 \mathrm{~mm}$, and maximum value of $0.3 \mathrm{~mm}$. These calculated $\mathrm{z}_{0}$ values are used for $\tau_{\mathrm{WC}}$ calculations. The behaviour of the Oissel mudflat during a semi-lunar cycle is examined in Fig. 9 in response to the variations in the bottom shear stress and the local $\mathrm{C}_{\mathrm{SPM}}$. The average tidal-induced shear stress (boat passages excluded) is low (less than $0.1 \mathrm{~N} \mathrm{~m}^{-2}$ ), which is explained by the weak tidal currents in the upper reach of the estuary (Verney et al., 2006). $\mathrm{C}_{\mathrm{SPM}}$ is low, ranging from 10 to $50 \mathrm{mg} \mathrm{l}^{-1}$ (Guezennec et al., 1999; Deloffre et al., 2005). These low hydrodynamic conditions are favourable for sedimentation: the altimetric survey shows a constant sedimentation rate of $0.2 \mathrm{~mm}$ per tide.

Short HEEs $\left(\tau_{\mathrm{wC}}>0.5 \mathrm{~N} \mathrm{~m}^{-2}\right)$ are recorded only irregularly (OI1, OI3, OI5, OI7, OI10); and they are associated with an increase in $\mathrm{C}_{\mathrm{SPM}}$ above $200 \mathrm{mg} \mathrm{l}^{-1}$ (Fig. 9a, b and c). Among all the HEEs reported, only one is correlated with a large and abrupt bed erosion (f $6 \mathrm{~mm}$ for OI10 - Fig 9d). This erosion event is clearly correlated with a boat passage, as indicated by bottom shear stress values higher than $0.5 \mathrm{~N} \mathrm{~m}^{-2}$. This event affected only a longshore line of the mudflat, where erosion is visible and indicated by a change in the bed surface: near the bank, the bed is flat and soft, and near the river, the bed is rough and scattered with muddy pebbles, typical of erosional events. All other HEEs observed during the survey were associated with a $\mathrm{C}_{\mathrm{SPM}}$ increase, but no net erosion was recorded by the 
altimeter during this survey: because of the local effect of boat-induced waves, this could correspond to erosion of another part of the mudflat, where bed shear stress exceeds the critical shear stress.

\section{Discussion}

\subsection{Processes of erosion: boat-induced waves}

Field measurements showed that barge passages in a narrow channel change the local hydrodynamics by generating a drawdown and packets of waves, and sometimes causing sediment resuspension (Fig. 4; Fig. 5; Fig. 9; Table 1). The drawdown is a low frequency variation of the water level, and its amplitude was reported to vary from 0.05 to $0.1 \mathrm{~m}$. Short waves are grouped in wave packets of wave height ranging from 0.05 to $0.15 \mathrm{~m}$. Boat passages cause short duration HEEs, which never exceeded 10 min. These observations are in agreement with the results of the field surveys and laboratory experiments reported by Parchure et al. (2001). These authors classified waves and drawdown intensities by boat type. They concluded that large vessels generated large drawdowns but low shortwave heights, contrary to leisure boats, which travel faster and thus generate small drawdowns but large short-wave heights. They also reported that barges induced more resuspension, with $\mathrm{C}_{\mathrm{SPM}}$ varying from 100 to $500 \mathrm{mg} \mathrm{l}^{-1}$ close to the bed. These concentrations are similar to those measured from the ADV backscattered intensity on the Oissel mudflat after barge passages. This might reflect the bed dislocation/liquefaction effect of the long waves, which would layer the first centimetres that could then be removed by short waves (De Wit and Kranenburg, 1997).

The water height time series indicate the passage of many boats. The most substantial events are reported in Table I, along with their principal hydrodynamic features. Relations between boat-induced flow variations, sediment resuspension, and bed erosion are difficult to establish, because they are related to various criteria such as water level, wave amplitude and frequency, bed form, and bed structure (Parchure et al., 2001). However, comparison of the local hydrodynamic variations and the response of the bed sediments shows that resuspension processes mainly occur during both high and 
low frequency velocity fluctuations (Table I, Boats 1, 5, 7 and 10). Low frequency current fluctuations occasionally generated low intensity resuspension (Table I, Boats 2, 4, 6, 8 and 9). Moreover, the erosion event observed by the ALTUS occurred when the average water height was the lowest, at approximately $0.3 \mathrm{~m}$, which suggests that water level is a critical parameter for erosion in the upper part of the estuary. Despite the low probability of such HEEs (as they require both boat passage and low water level), their amplitudes demonstrate that boat traffic plays an important role at the annual scale in mudflat dynamics and sediment fluxes in the upper estuary. This is confirmed by Deloffre et al. (2005), who reported three or four periods of abrupt erosion per year during a two-year survey above the Oissel Mudflat. These large erosion processes occurred after a period of deposition of several centimetres, when bed sediment bulk densities and critical erosion shear stress are the lowest.

This emphasizes the need for further examination of very shallow water processes. The influence of boat-induced waves as they break on the mudflat, when the turbulent intensity is at its highest, is of special interest.

\subsection{Bed sediment erodibility and critical erosion shear stress}

The turbulent threshold effect on mudflat sediment erosion processes has been researched extensively over the last 30 years. This threshold effect is especially relevant for mathematical modelling of sediment transport, which uses the critical erosion shear stress as a major controlling parameter (Sanford and Maa, 2001). Many instruments have been developed to estimate this threshold in field studies or in laboratory flumes (Mitchener and Torfs, 1996; Black and Paterson, 1997; Tolhurst et al., 2000). All these instruments are based on the same experimental protocol, i.e. the shear stress applied is controlled and increased stepwise, and the erosion threshold is reached when the operator observes that $\mathrm{C}_{\mathrm{SPM}}$ shows a substantial increase or exceeds a fixed level of $\mathrm{C}_{\mathrm{SPM}}$ or turbidity. Similar measurements of the critical erosion shear stress can be carried out in situ by comparing time series of bottom shear stress values to erosion criteria, i.e. $\mathrm{C}_{\mathrm{SPM}}$ and bed height measured by ADV and ALTUS devices. 
Those two methods are applied for the Oissel mudflat measurements. A comparison of $\mathrm{C}_{\mathrm{SPM}}$ values and $\tau_{\mathrm{WC}}$ values (Fig. 9 and 10) shows that substantial resuspension occurred when $\tau_{\mathrm{WC}}$ was above 0.2 $\mathrm{N} \mathrm{m}^{-2}$, except for OI1 where no concentration increase was observed. Based on bed elevation measurements, bed erosion occurred abruptly and only once during the study, and was associated with high $\tau_{\mathrm{WC}}$ values (between 0.3 and $0.8 \mathrm{~N} \mathrm{~m}^{-2}$ ). The bed sediments of the Oissel mudflat are sandy-mud with a thin layer of newly deposited sediments, as observed by the altimetric survey (Fig. 9). The critical shear stress value calculated from the relation provided by Mitchener and Torfs (1996) for sandy-mud sediments is $0.6 \mathrm{~N} \mathrm{~m}^{-2}$, which is in the range of the $\tau_{\text {ce }}$ value estimated. However, the altimeter did not measure any variation of the bed elevation during these events. This could be either because the erosion affected only the thin upper layer of fluid mud deposited at the surface, the erosion thickness being smaller than the ALTUS vertical resolution, or more probably because erosion occurred elsewhere on the mudflat. Unlike devices dedicated to erosion threshold determination that work with a confined controlled volume of water, the $\mathrm{C}_{\text {SPM }}$ method used in situ to determine $\tau_{\text {ce }}$ is subjected to variations in both the intensity of the hydrodynamic processes and in the bed sediment properties. Therefore, an increase in $\mathrm{C}_{\mathrm{SPM}}$ observed by the ADV may be the result of bed erosion away from the sampling site and thus not measurable by the ALTUS altimeter, the resuspended sediment being then advected through the ADV sampling volume as modelled and discussed by Brun-Cottan et al. (2000).

Estimating critical erosion shear stress is more complex at the estuary mouth: this site is influenced by the turbidity maximum zone, and so the background $\mathrm{C}_{\mathrm{SPM}}$ is naturally highly variable, and ranges from 10 to $1000 \mathrm{mg} \mathrm{l}^{-1}$ (Lesourd et al., 2003; Deloffre et al., 2005). The $\mathrm{C}_{\mathrm{SPM}}$ method therefore cannot be applied to determine $\tau_{\text {ce, }}$ and only the altimetric measurements are used (Fig. 7). The results demonstrate that deposition periods correspond to $\tau_{\mathrm{WC}}$ values below a critical value of $0.8 \mathrm{~N} \mathrm{~m}^{-2}$, and the lower the $\tau_{\mathrm{wC}}$, the higher the deposition rate. Erosion processes take place for $\tau_{\mathrm{WC}}$ values higher than $1 \mathrm{~N} \mathrm{~m}^{-2}$. The relation between erosion rate and bed sediment properties is clearly observed: all erosion events that occur after a period of deposition have an erosion rate that ranges from 0.1 to 0.165 
$\mathrm{g} \mathrm{m}^{-2} \mathrm{~s}^{-1}$ (VN2 to VN5). During VN5 and VN6, the erosion rate decreased from 0.1 to $0.035 \mathrm{~g} \mathrm{~m}^{-2} \mathrm{~s}^{-1}$,

580

581

582

583

584

585

586

587

588

589

590

591

592

593

594

595

596

597

598

599

600

601

602

603

604

605

606

whereas the mean shear rate was similar during these two tides $\left(1.5 \mathrm{~N} \mathrm{~m}^{-2}\right)$. During VN5, the bed surface sediment had been newly deposited during the previous tides, and should be characterised by a lower bulk density and a lower critical erosion shear stress. During this tide, all newly deposited sediments were removed and the bed level reached was lower than at any time during the previous four days. Therefore, bed sediments during VN6 had been subjected to consolidation processes for several days and should feature higher bulk densities and higher critical erosion shear stress, which would explain the lower erosion rate during VN6. The critical erosion shear stress value of $1 \mathrm{~N} \mathrm{~m}^{-2}$ is in the upper range of the critical erosion shear stress measured by Mitchener and Torfs (1996) for newly-deposited muddy bed sediments and which ranges from 0.1 to $1.5 \mathrm{~N} \mathrm{~m}^{-2}$.

The differences between critical erosion shear stress values calculated in this study and the values proposed in the literature may be the results of differences in the hydrodynamic processes observed. Most of the knowledge of erosion and deposition processes of muddy sediments is based on studies that taking into account only the current velocities (Tolhurst et al., 2000). In contrast, this study examined the impact of wave-induced shear stress on mudflat dynamics. Currently, our understanding of the interaction between wave-induced shear stress, muddy sediment erodibility, and bed sediment properties is limited to field observations (Winterwerp and van Kesteren, 2004). Thus, further research is required to provide a better understanding of current only, wave only and current-wave erosion processes in relation to muddy bed sediment properties.

\section{Conclusions}

The combined use of high frequency and high resolution altimetric measurements and near bottom sediment hydrodynamic measurements during both tidal and semi-lunar surveys identified and quantified wind and boat passage events and their impact on mudflats. The tidal surveys allowed continuous recording of the current velocity and water height fluctuations. These measurements allowed quantification of the boat- and wind- induced wave contributions to the bottom shear stress. 
607 Bed elevation, bottom shear stress, and suspended particulate matter concentration measurements

608 close to the bottom were used to determine critical erosion and deposition shear stresses.

609

610 The fluvial part of the Seine estuary is affected by boat traffic. Boat-induced waves show a bimodal 611 pattern, with long and short waves, and generate bottom shear stresses stronger than $0.5 \mathrm{~N} \mathrm{~m}^{-2}$ for a 612 few minutes with peaks up to $1 \mathrm{~N} \mathrm{~m}^{-2}$. In most cases, boat passages generate sediment resuspension 613 when bottom shear stress values exceeded $0.2 \mathrm{~N} \mathrm{~m}^{-2}$. Large erosion processes (erosion of more than a

$6145 \mathrm{~mm}$ thickness) are observed under specific conditions such as low water height $(\mathrm{h}<30 \mathrm{~cm})$ and high 615 amplitude waves. Low amplitude erosion processes are observed at very shallow water depths at the 616 beginning of the flood tide and at the end of the ebb tide, which could be caused by tidal currents or 617 boat passages. These observations highlight the need for further research on the effect of both very 618 shallow water processes and emersion/immersion processes on sediment dynamics.

620 At the mouth of the Seine estuary (Vasière Nord Mudflat), W-SW wind events generate waves with a 621 significant wave height of 0.1 to $0.3 \mathrm{~m}$ for wind speeds ranging from 7 to $15 \mathrm{~m} \mathrm{~s}^{-1}$. Wind waves induce 622 bottom shear stress values higher than $0.5 \mathrm{~N} \mathrm{~m}^{-2}$ and up to $2 \mathrm{~N} \mathrm{~m}^{-2}$. These results confirm that W-SW 623 wind events are the predominant forcing parameter for mudflat dynamics at the estuary mouth. Critical deposition shear stress is estimated to $0.8 \mathrm{~N} \mathrm{~m}^{-2}$ and critical erosion shear stress to be $1 \mathrm{~N} \mathrm{~m}^{-2}$. 


\section{Acknowledgments}

626

627 Funding for this study was provided partly by the European INTERREG III RIMEW program and the 628 Seine Aval Program. Romaric Verney was funded through a grant provided by the Regional Council 629 of Haute Normandie (France). We would like to thank Mrs Dilys Moscato and Mrs Barbara Malher 630 for their helpful review and Michel Simon for his technical support on field. Two anonymous 631 reviewers are thanked for their helpful comments and useful corrections that greatly improved this 632 work. 


\section{References}

634

635

Allen, J. R. L. and Duffy, M. J. (1998) Temporal and spatial depositional patterns in the Severn

Estuary, southwestern Britain: intertidal studies at spring-neap and seasonal scales, 1991-1993. Marine

Geology, 146 (1-4) 147-171

638

Bassoullet, P., Le Hir, P., Gouleau, D. and Robert, S. (2000) Sediment transport over an intertidal mudflat: field investigations and estimation of fluxes within the "Baie de Marennes-Oleron" (France).

642

Black, K. S. and Paterson, D. M. (1997) Measurement of the erosion potential of cohesive marine sediments: a review of current in situ technology. Journal of Marine Environmental Engineering, 4 4383

646

Brun-Cottan, J.-C., Guillou, S. and Li, Z. H. (2000) Behaviour of a puff of resuspended sediment : a conceptual model. Marine Geology, 167 355-373

649

650

Collins, M. B., Ke, X. and Gao, S. (1998) Tidally-induced flow structure over intertidal flats.

652

Cundy, A. B., Hopkinson, L., Lafite, R., Spencer, K., Taylor, J. A., Ouddane, B., Heppell, C. M.,

Carey, P. J., Charman, R., Shell, D. and Ullyott, S. (2005) Heavy metal distribution and accumulation

in two Spartina sp.-dominated macrotidal salt marshes from the Seine estuary (France) and the

Medway estuary (UK). Applied Geochemistry, 20 1195-1208

657

De Wit, P. J. and Kranenburg, C. (1997) The wave-induced liquefaction of cohesive sediment beds. 
664

665

666

667

668

669

670

671

672

673

674

675

676

677

678

679

680

681

682

683

684

685

686

687

688

Deloffre, J., Lafite, R., Lesueur, P., Lesourd, S., Verney, R. and Guezennec, L. (2005) Sedimentary processes on an intertidal mudflat in the upper macrotidal Seine estuary, France. Estuarine, Coastal and Shelf Science, 64 (4) 710-720

Deloffre, J., Lafite, R., Lesueur, P., Verney, R., Lesourd, S., Cuvilliez, A. and Taylor, J. A. (In press) Controlling factors of rhythmic sedimentation processes on an intertidal estuarine mudflat - Role of the maximum turbidity zone in the macrotidal Seine estuary, France. Marine Geology,

Dyer, K. R. (1994) Estuarine Sediment transport and deposition. In: Pye, K. (Eds), Sediment transport and depositional processes, Blackwell Scientific Publications, 193-217

Fagerburg, T. L. and Pratt, T. C. (1998) Upper Mississippi River navigation and sedimentation field data collection summary report. In: Interim Report for the upper Mississippi River - Illinois waterway System navigation study, US Army Corps of Engineers (Eds), 150pp

Fredsoe, J. (1984) Turbulent boundary layer in wave-current motion. Journal of Hydraulic Engineering, 110 1103-1120

Fugate, D. C. and Friedrichs, C. T. (2002) Determining concentration and fall velocity of estuarine particle populations using ADV, OBS and LISST. Continental Shelf Research, 22 1867-1886

Grant, J. and Madsen, O. S. (1979) Combined wave and current interaction with a rough bottom. Journal of Geophysical Research, 84 (C4) 1797-1808

Guezennec, L., Lafite, R., Dupont, J. P., Meyer, R. and Boust, D. (1999) Hydrodynamics of suspended particulate matter in the tidal freshwater zone of a macrotidal estuary (the Seine estuary, France).

Estuaries, 22 (3A) 717-727 
Huntley, D. A. (1988) A modified inertial dissipation method for estimating seabed stresses at low

690 Reynolds numbers, with application to wave/current boundary layer measurements. Journal of 691 Physical Oceanography, 18 339-346

692

693

Hutnance, J. M., Humphery, J. D., Knight, P. J., Chatwin, P. G., Thomsen, L. and White, M. (2002)

Near-bed turbulence measurements, stress estimates and sediment mobility at the continental shelf

696

Kawanisi, K. and Yokosi, S. (1997) Characteristics of suspended sediment and turbulence in a tidal

Kim, S.-C., Friedrichs, C. T., Maa, J. P.-Y. and Wright, L. D. (2000) Estimating bottom stress in tidal

Lafite, R. and Romana, L. A. (2001) A man-altered macrotidal estuary : the Seine estuary (France).

Le Hir, P., Roberts, W., Cazaillet, O., Christie, M. C., Bassoullet, P. and Bacher, C. (2000)

Characterization of intertidal flat hydrodynamics. Continental Shelf Research, 20 1433-1459

Lesourd, S. (2000) Processus d'envasement d'un estuaire macrotidal: zoom temporel du siècle à 
Lesourd, S., Lesueur, P., Brun-Cottan, J. C., Garnaud, S. and Poupinet, N. (2003) Seasonal variations

718

719

720

721

722

723

724

725

726

727

728

729

730

731

732

733

734

735

736

737

738

739

740

741

742

743

744

in the characteristics of superficial sediments in a macrotidal estuary (the Seine inlet, France).

Estuarine, Coastal and Shelf Science, 58 (1) 3-16

Mitchener, H. and Torfs, H. (1996) Erosion of mud/sand mixtures. Coastal Engineering, 29 1-25

Myrhaug, D., Slaattelid, O. H. and Lambrakos, K. F. (1998). Seabed shear stresses under random waves: prediction vs estimates from field measurements. Ocean Engineering 25(10) 907-916.

O'Brien, D. J., Whitehouse, R. J. S. and Cramp, A. (2000) The cyclic development of a macrotidal mudflat on varying timescales. Continental Shelf Research, 20 (12-13) 1593-1619

Parchure, T. M., McAnally, W. H. and Teeter, A. M. (2001) Wave-induced sediment resuspension near the shorelines of the upper Mississippi river system. In: Interim Report for the upper Mississippi River - Illinois waterway System navigation study, US Army Corps of Engineers (Eds), 31p

Sanford, L. P. and Maa, J. P.-Y. (2001) A unified erosion formulation for fine sediments. Marine Geology, 179 9-23

Schoellhamer, D. H. (1996) Anthropogenic sediment resuspension mechanisms in a shallow microtidal estuary. Estuarine, Coastal and Shelf Science, 43 533-548

Silva Jacinto, R. (2002) Action des vagues sur les estrans et vasières. Application à l'estuaire de Seine. PhD Thesis, Université de Rouen, 231pp.

Simpson, J. H., Williams, E., Brasseur, L. H. and Brubaker, J. M. (2005) The impact of tidal straining on the cycle of turbulence in a partially stratified estuary. Continental Shelf Research, 25 51-64 
Soulsby, R. L. (1983) The bottom boundary layer of shelf seas. In: Johns, B. (Eds), Physical oceanography of coastal and shelf seas, Elsevier, 189-266

Soulsby, R. L. (1995) Bed shear stress due to combined waves and currents. In: Stive, M. J. F., de

Vriend, H. J., Fredsoe, J., Hamm, L., Soulsby, R. L., Teisson, C. and Winterwerp, J. C. (Eds),

Advances in coastal moprhodynamics, Delft Hydraulics, 4:20-4:23

751

752

Soulsby, R. L. (1997) Dynamics of marine sands. A manual for practical applications. Thomas

Telford, London,249p.

754

755

Soulsby, R. L., Hamm, L., Klopman, G., Myrhaug, D., Simons, R. R. and Thomas, G. P. (1993)

756

Wave-current interaction within and outside the bottom boundary layer. Coastal Engineering, 21 41-69

757

758

Soulsby, R. L. and Humphery, J. D. (1990) Field observations of wave-current interaction at the sea

bed. In: Torum, A. and Gudmestad, O. T. (Eds), Water wave kinematics, Kluwer Academic

760

Publishers, 413-428

761

762

Talke, S. A. and Stacey, M. T. (2003) The influence of oceanic swell on flows over an estuarine intertidal mudflat in San Francisco Bay. Estuarine, Coastal and Shelf Science, 58 541-554

764

765

766

Thorne, P. D. and Hanes, D. M. (2002) A review of acoustic measurements of small-scale sediment processes. Continental Shelf Research, 22 603-632

767

768

Tolhurst, T. J., Black, K. S., Paterson, D. M., Mitchener, H. J., Termaat, G. R. and Shayler, S. A.

(2000) A comparison and measurement standardisation of four in situ devices for determining the 
Trembanis, A. C., Wright, L. D., Friedrichs, C. T., Green, M. O. and Hume, T. (2004) The effects of

773

774

775

776

777

778

779

780

781

782

783

784

785

786

787

788

789

790

791

792

793

794

795

796

797

spatially complex inner shelf roughness on boundary layer turbulence and current and wave friction:

Tairua embayment, New Zealand. Continental Shelf Research, 24 (13-14) 1549-1571

Uncles, R. J., Easton, A. E., Griffiths, M. L., Harris, C. K., Howland, R. J. M., King, R. S., Morris, A. W. and Plummer, D. H. (1998) Seasonality of the turbidity maximum in the Humber-Ouse Estuary, UK. Marine Pollution Bulletin, 37 (3-7) 206-215

Verney, R., Brun Cottan, J. C., Lafite, R., Deloffre, J. and Taylor, J. A. (2006) Tidal-induced shear stress variability above intertidal mudflats. Case of the macrotidal Seine estuary. Estuaries, 29 (4) 653664

Voulgaris, G. and Meyers, S. T. (2004) Temporal variability of hydrodynamics, sediment concentration and sediment settling velocity in a tidal creek. Continental Shelf Research, 24 (15) $1659-1683$

Voulgaris, G. and Trowbridge, J. H. (1998) Evaluation of the acoustic doppler velocimeter (ADV) for turbulence measurements. Journal of Atmospheric and Oceanic Technology, 15 272-289

Williams, J. J., Rose, C. P., Thorne, P. D., O'Connor, B. A., Humphery, J. D., Hardcastle, P. J., Moores, S. P., Cooke, J. A. and Wilson, D. J. (1999) Field observations and predictions of bed shear stresses and vertical suspended sediment concentration profiles in wave-current conditions. Continental Shelf Research, 19 507-536

Winterwerp, J. C. and van Kesteren, W. G. M. (2004) Introduction to the physics of cohesive sediment in the marine environment. Elsevier, Amsterdam, 558pp. 


\section{Figure Caption}

799

800

Table I: Summary of hydrodynamic features (Significant wave height and maximum velocity

801

fluctuations), suspended particulate matter concentration and bed elevation measurements during boat

802

passages above the Oissel intertidal mudflat. $\left(\mathrm{H}_{\mathrm{S}} \mathrm{LW}\right.$ : significant long-wave height; $\mathrm{H}_{\mathrm{S}} \mathrm{SW}$ :

803

significant short-wave height; $\Delta \mathrm{U}$ LW : long-wave-induced velocity fluctuation; $\Delta \mathrm{U}$ SW : short-wave-

804 induced velocity fluctuation)

805

806

Fig. 1: The Seine estuary and study sites: The Oissel Mudflat (kp 230) in the upper estuary and the Vasière Nord mudflat (kp 355) at the estuary mouth. Position of the instrumented MAREL Buoy.

808 (Kilometric point (kp): distance from the Pont Marie, Paris) (Channel width exaggerated upstream kp 350 to clarify the figure)

810

Fig. 2: Calibration of the $6 \mathrm{MHz}$ Nortek ADV backscattered amplitude with weighted suspended sediment concentration: experimental results (this study) and data from Voulgaris and Meyer (2004) from a $10 \mathrm{MHz}$ Sontek ADV

814

Fig. 3: Hydrodynamic features during a W-SW $8 \mathrm{~m} \mathrm{~s}^{-1}$ wind event above the Vasière Nord intertidal mudflat: (a) instantaneous wave height; (b) significant wave height $\left(\mathrm{H}_{\mathrm{S}}\right)$ and period (T) over a one minute period; (c) TKE shear stress ( $\tau_{\mathrm{TKE}}$ ), and Wave-Current shear stress ( $\tau_{\mathrm{WC}}$ ) for a bed roughness length of $0.37 \mathrm{~mm}$. The shadow area shows the $\tau_{\mathrm{WC}}$ variability as a function of low $(0.2 \mathrm{~mm})$ or large $(0.7 \mathrm{~mm})$ bed roughness length

820

Fig. 4: Boat passages above the Oissel intertidal mudflat: (a) Wave height during the tidal cycle and 
Fig. 5: Typical hydrodynamic signature of a boat passage above the Oissel intertidal mudflat : (a) wave height ; (b) long wave height and (c) short wave height; (d) short waves $\left(\tau_{\mathrm{W}-\mathrm{sw}}\right)$, long waves $\left(\tau_{\mathrm{W}-}\right.$ LW) and combined short-long waves $\left(\tau_{\mathrm{W}-\mathrm{LW}+\mathrm{SW}}\right)$ shear stresses and (e) bottom shear stress calculations : combined short-long waves $\left(\tau_{\mathrm{W}-\mathrm{LW}+\mathrm{SW}}\right)$ shear stress, wave-current shear stress $\left(\tau_{\mathrm{WC}}\right)$ and TKE shear stress $\left(\tau_{\mathrm{TKE}}\right)$

829

Fig. 6: Impact of boat passages on hydrodynamic features above the Oissel mudflat during a tidal cycle: (a) mean water level and mean current velocity (U) and (b) wave-current shear stress ( $\left.\tau_{\mathrm{wC}}\right)$ and TKE shear stress $\left(\tau_{\mathrm{TKE}}\right)$.

833

Fig. 7: Variability of hydrodynamic and sedimentary parameters during high spring tides above the Vasière Nord mudflat. (a) water level; (b) wind speed and direction measured at the MAREL Buoy; (c) significant wave height $\left(\mathrm{H}_{\mathrm{S}}\right)$; (d) wave-current shear stress $\left(\tau_{\mathrm{WC}}\right)$; (e) SPM concentration $\left(\mathrm{C}_{\mathrm{SPM}}\right)$ and (f) bed elevation variations. Sedimentation periods are indicated by grey dots and the erosion periods by black dots

839

Fig. 8: Variability of the bed roughness length during a fortnightly survey at the Oissel Mudflat.

Fig. 9: Variability of hydrodynamic and sedimentary parameters during a semi-lunar cycle above the

Oissel mudflat. (a) water level; (b) wave-current shear stress ( $\left.\tau_{\mathrm{WC}}\right)$; (c) SPM concentration $\left(\mathrm{C}_{\mathrm{SPM}}\right)$ and

(d) bed elevation variations

845

Figure 10: Comparison between bottom shear stress ( $\left.\tau_{\mathrm{WC}}\right)$ and SPM concentration $\left(\mathrm{C}_{\mathrm{SPM}}\right)$ values above the Oissel Mudflat: determination of the critical erosion shear stress 


\section{Figure Caption}

Table I: Summary of hydrodynamic features (Significant wave height and maximum velocity fluctuations), Suspended Particulate Matter concentration and bed elevation measurements during boat passages above the Oissel intertidal mudflat. $\left(\mathrm{H}_{\mathrm{S}} \mathrm{LW}\right.$ : significant long-wave height; $\mathrm{H}_{\mathrm{S}} \mathrm{SW}$ : significant short-wave height; $\Delta \mathrm{U} \mathrm{LW}$ : long-wave-induced velocity fluctuation; $\Delta \mathrm{U}$ SW : short-waveinduced velocity fluctuation)

Fig. 1: The Seine estuary and sites studied: The Oissel Mudflat (kp 230) in the upper estuary and the Vasière Nord mudflat (kp 355) at the estuary mouth. Position of the instrumented MAREL Buoy. (Kilometric point (kp): distance from the Pont Marie, Paris) (Channel width exaggerated upstream kp 350 to clarify the figure)

Fig. 2: Calibration of the $6 \mathrm{MHz}$ Nortek ADV backscattered amplitude with weighted suspended sediment concentration : experimental results (this study) and data from Voulgaris and Meyer (2004) from a $10 \mathrm{MHz}$ Sontek ADV

Fig. 3: Hydrodynamic features during a W-SW $8 \mathrm{~m} \mathrm{~s}^{-1}$ wind event above the Vasière Nord intertidal mudflat: (a) instantaneous wave height; (b) significant wave height $\left(\mathrm{H}_{\mathrm{S}}\right)$ and period (T) over a one minute period; (c) TKE shear stress ( $\tau_{\mathrm{TKE}}$ ), and Wave-Current shear stress ( $\tau_{\mathrm{WC}}$ ) for a bed roughness length of $0.37 \mathrm{~mm}$. The shadow area shows the $\tau_{\mathrm{WC}}$ variability as a function of low $(0.2 \mathrm{~mm})$ or large $(0.7 \mathrm{~mm})$ bed roughness length

Fig. 4: Boat passages above the Oissel intertidal mudflat: (a) Wave height during the tidal cycle and zoom on one boat passage : (b) wave height (c) and 3D current velocity variations. 
Fig. 5: Typical hydrodynamic signature of a boat passage above the Oissel intertidal mudflat : (a) wave height ; (b) long wave height and (c) short wave height; (d) short waves $\left(\tau_{\mathrm{W}-\mathrm{sw}}\right)$, long waves $\left(\tau_{\mathrm{W}-}\right.$ LW) and combined short-long waves $\left(\tau_{\mathrm{W}-\mathrm{LW}+\mathrm{SW}}\right)$ shear stresses and (e) bottom shear stress calculations : combined short-long waves $\left(\tau_{\mathrm{W}-\mathrm{LW}+\mathrm{SW}}\right)$ shear stress, wave-current shear stress $\left(\tau_{\mathrm{WC}}\right)$ and TKE shear stress $\left(\tau_{\mathrm{TKE}}\right)$

Fig. 6: Impact of boat passages on hydrodynamic features above the Oissel mudflat during a tidal cycle: (a) mean water level and mean current velocity (U) and (b) Wave-current shear stress ( $\left.\tau_{\mathrm{wc}}\right)$ and TKE shear stress $\left(\tau_{\mathrm{TKE}}\right)$.

Fig. 7: Variability of hydrodynamic and sedimentary parameters during high spring tides above the Vasière Nord mudflat. (a) water level; (b) wind speed and direction measured at the MAREL Buoy; (c) significant wave height $\left(\mathrm{H}_{\mathrm{S}}\right)$; (d) wave-current shear stress $\left(\tau_{\mathrm{WC}}\right)$; (e) SPM concentration $\left(\mathrm{C}_{\mathrm{SPM}}\right)$ and (f) bed elevation variations. Sedimentation periods are indicated by grey dots and the erosion periods by black dots

Fig. 8: Variability of the bed roughness length during a fortnightly survey at the Oissel Mudflat.

Fig. 9: Variability of hydrodynamic and sedimentary parameters during a semi-lunar cycle above the Oissel mudflat. (a) water level; (b) wave-current shear stress ( $\left.\tau_{\mathrm{WC}}\right)$; (c) SPM concentration ( $\left.\mathrm{C}_{\mathrm{SPM}}\right)$ and (d) bed elevation variations

Figure 10: Comparison between bottom shear stress $\left(\tau_{\mathrm{WC}}\right)$ and SPM concentration $\left(\mathrm{C}_{\mathrm{SPM}}\right)$ values above the Oissel Mudflat: determination of the critical erosion shear stress 
Table I

\begin{tabular}{|c|c|c|c|c|c|c|c|}
\hline Boat $\mathrm{Nb}$ & $\begin{array}{c}\text { Water height } \\
\text { above the bed }(\mathrm{m})\end{array}$ & Hs LW (m) & Hs SW (m) & $\diamond \mathrm{U} \operatorname{LW}\left(\mathrm{m} \mathrm{s}^{-1}\right)$ & $\diamond \cup \mathrm{SW}\left(\mathrm{m} \mathrm{s}^{-1}\right)$ & $\begin{array}{c}\text { Resuspension } \\
\left(\mathrm{mg} \mathrm{l}^{-1}\right)\end{array}$ & Erosion $(\mathrm{mm})$ \\
\hline 1 & 0.7 & 0.1 & 0.15 & 0.15 & 0.2 & 500 & $\mathrm{NO}$ \\
\hline 2 & 0.35 & - & - & 0.15 & 0 & 100 & NO \\
\hline 3 & 0.35 & 0.1 & 0.08 & 0.05 & 0.15 & 100 & NO \\
\hline 4 & 0.5 & 0.05 & 0 & 0.1 & 0 & 0 & NO \\
\hline 5 & 0.55 & 0.2 & 0.05 & 0.5 & 0.1 & 500 & NO \\
\hline 6 & 0.3 & - & - & 0.1 & 0 & 0 & NO \\
\hline 7 & 0.4 & - & - & 0.1 & 0.2 & 450 & NO \\
\hline 8 & 1.4 & 0.05 & 0.05 & 0.1 & 0.05 & 50 & NO \\
\hline 9 & 0.5 & 0.05 & 0 & 0.1 & 0 & 0 & NO \\
\hline 10 & 0.2 & - & - & 0.3 & 0.2 & 1500 & 6 \\
\hline
\end{tabular}


Figure 1

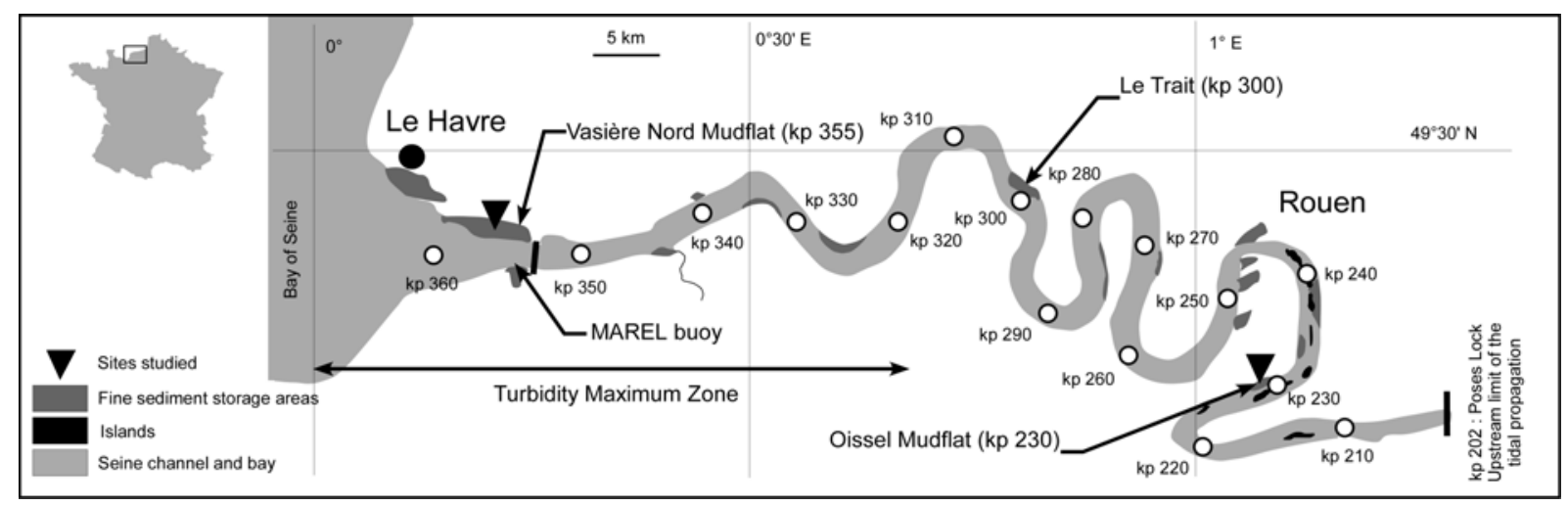


Figure 2

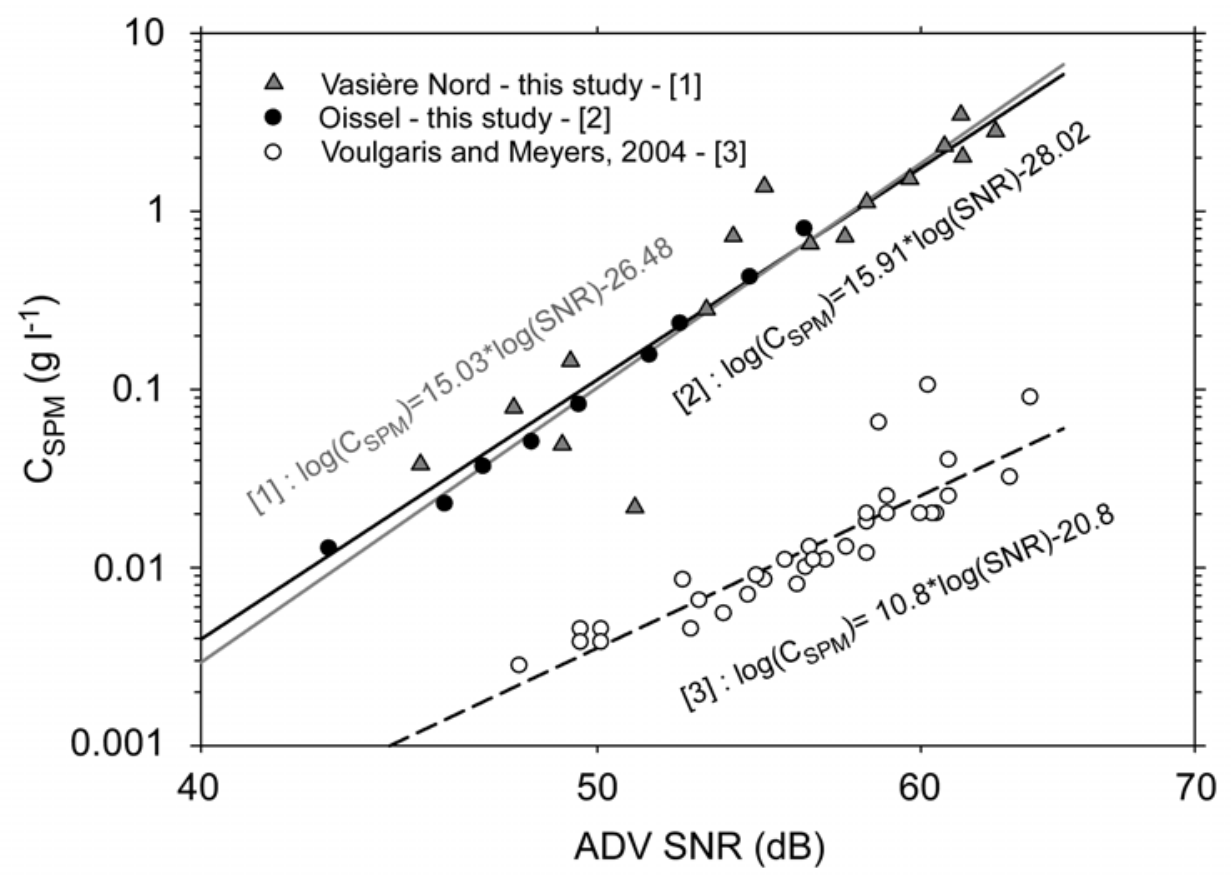


Figure 3
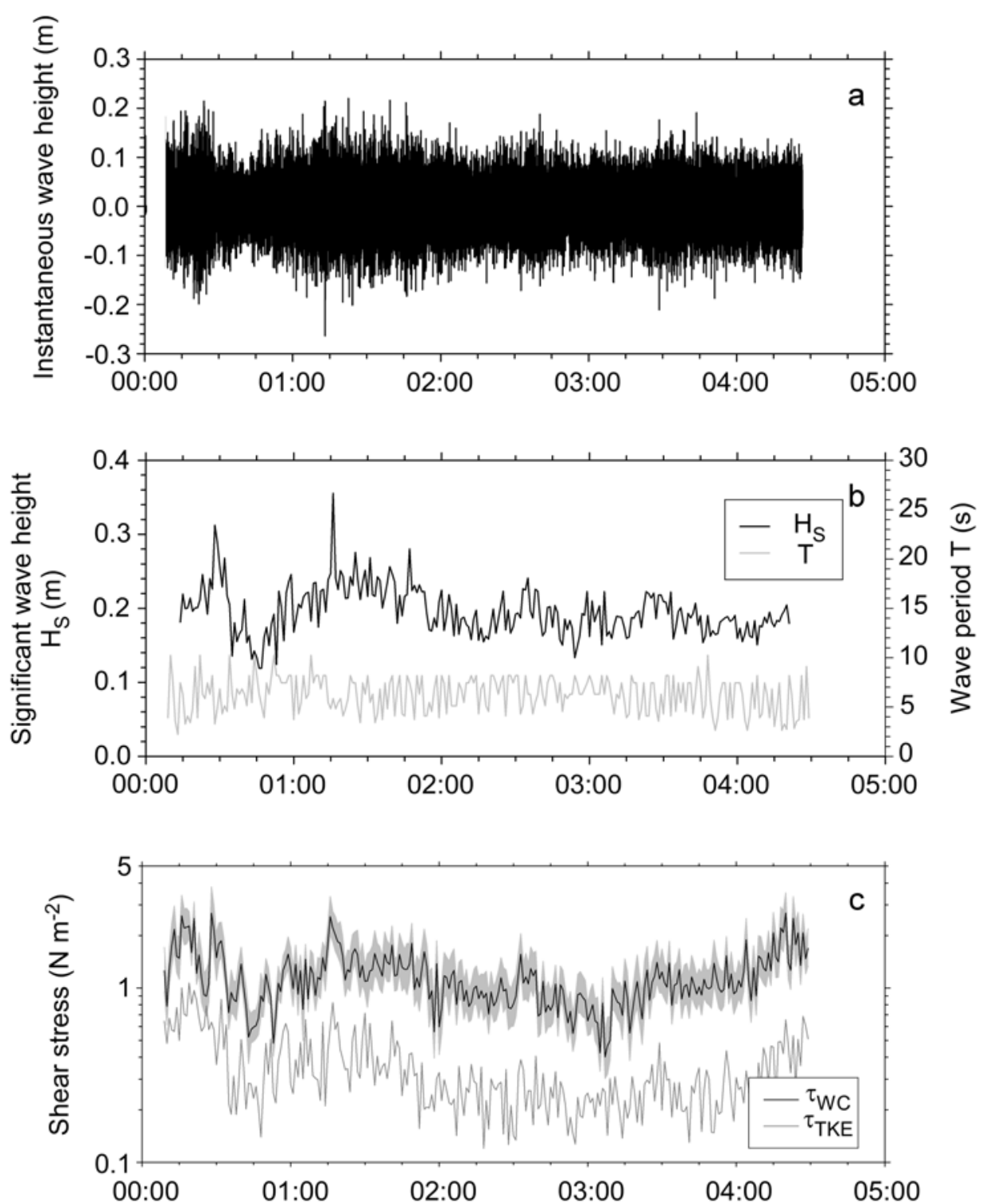
Figure 4
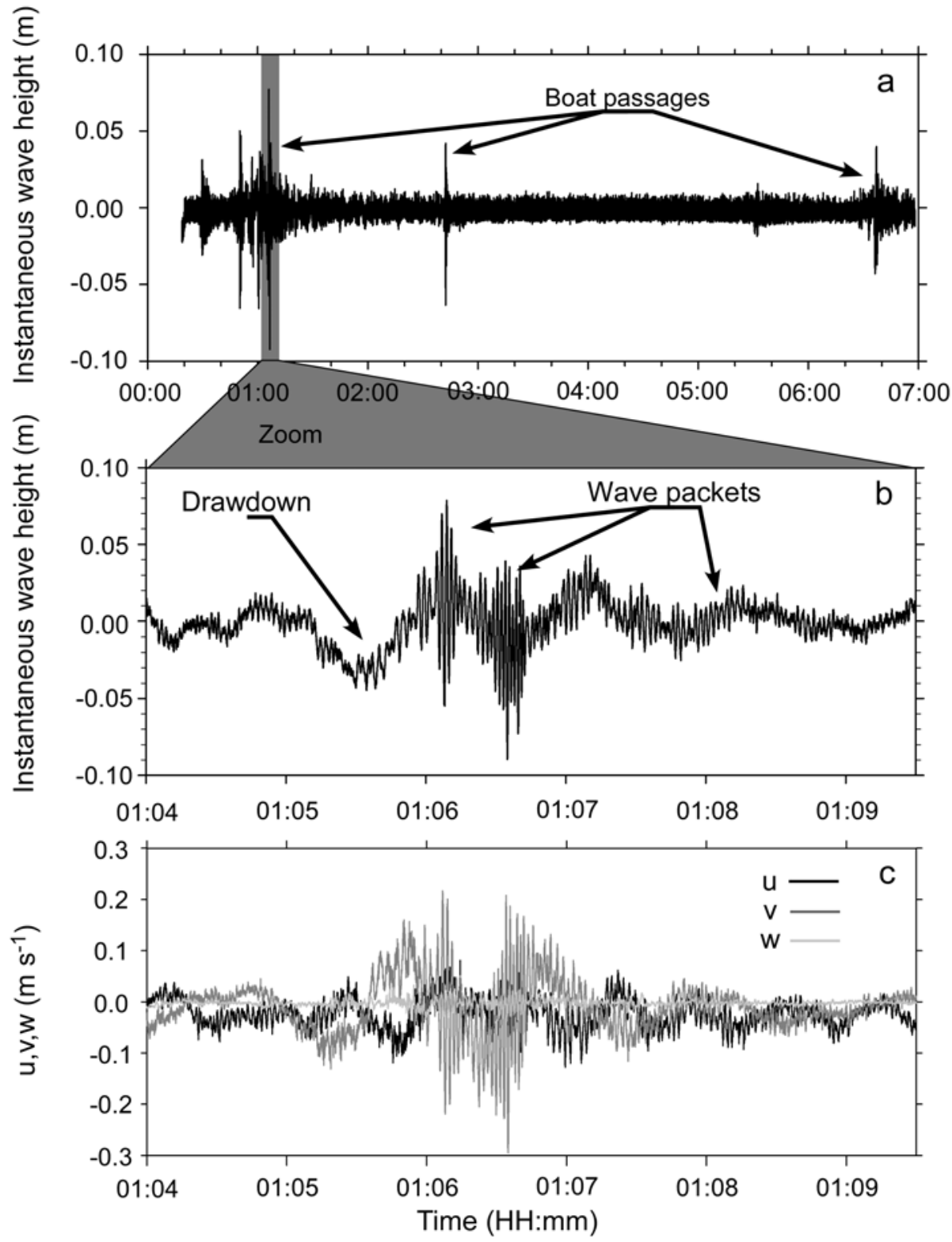
Figure 5
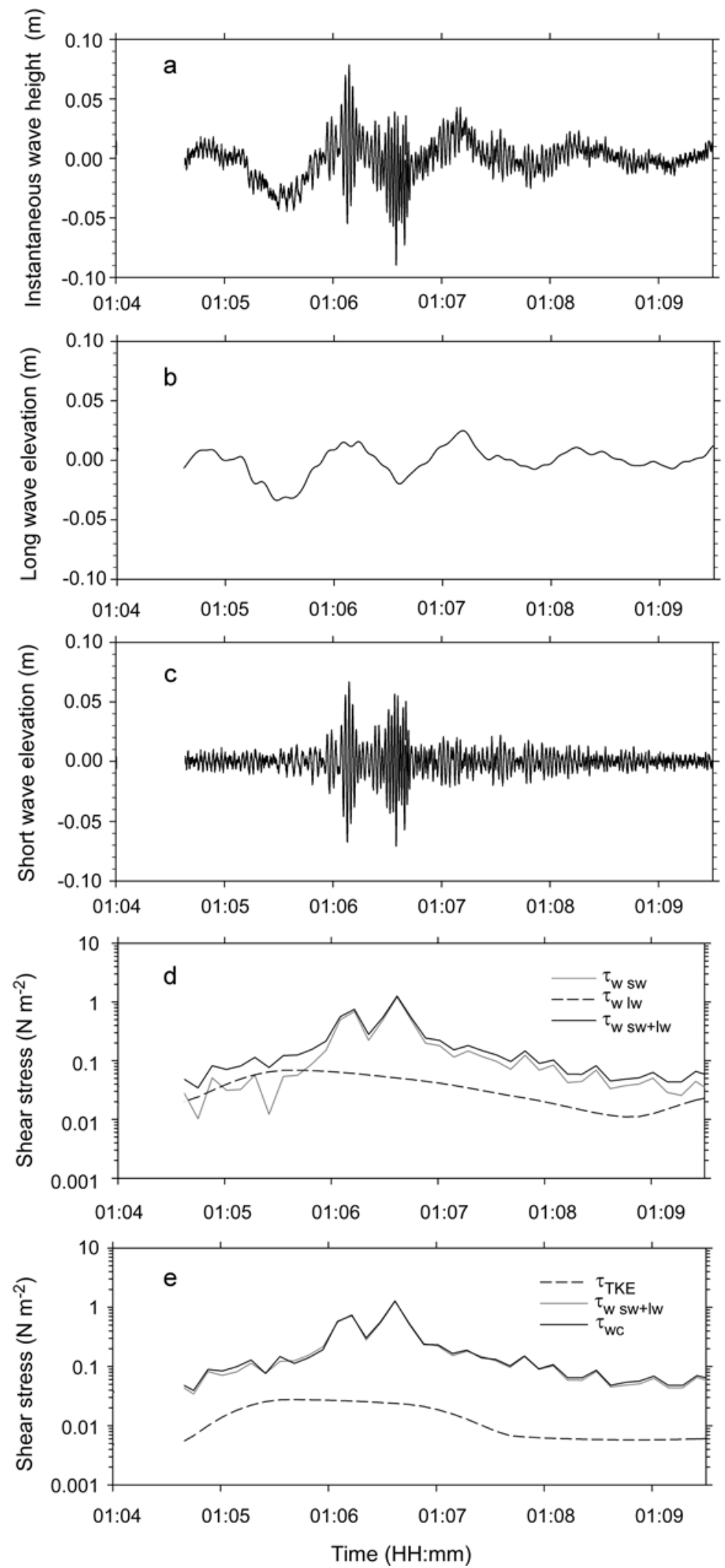
Figure 6
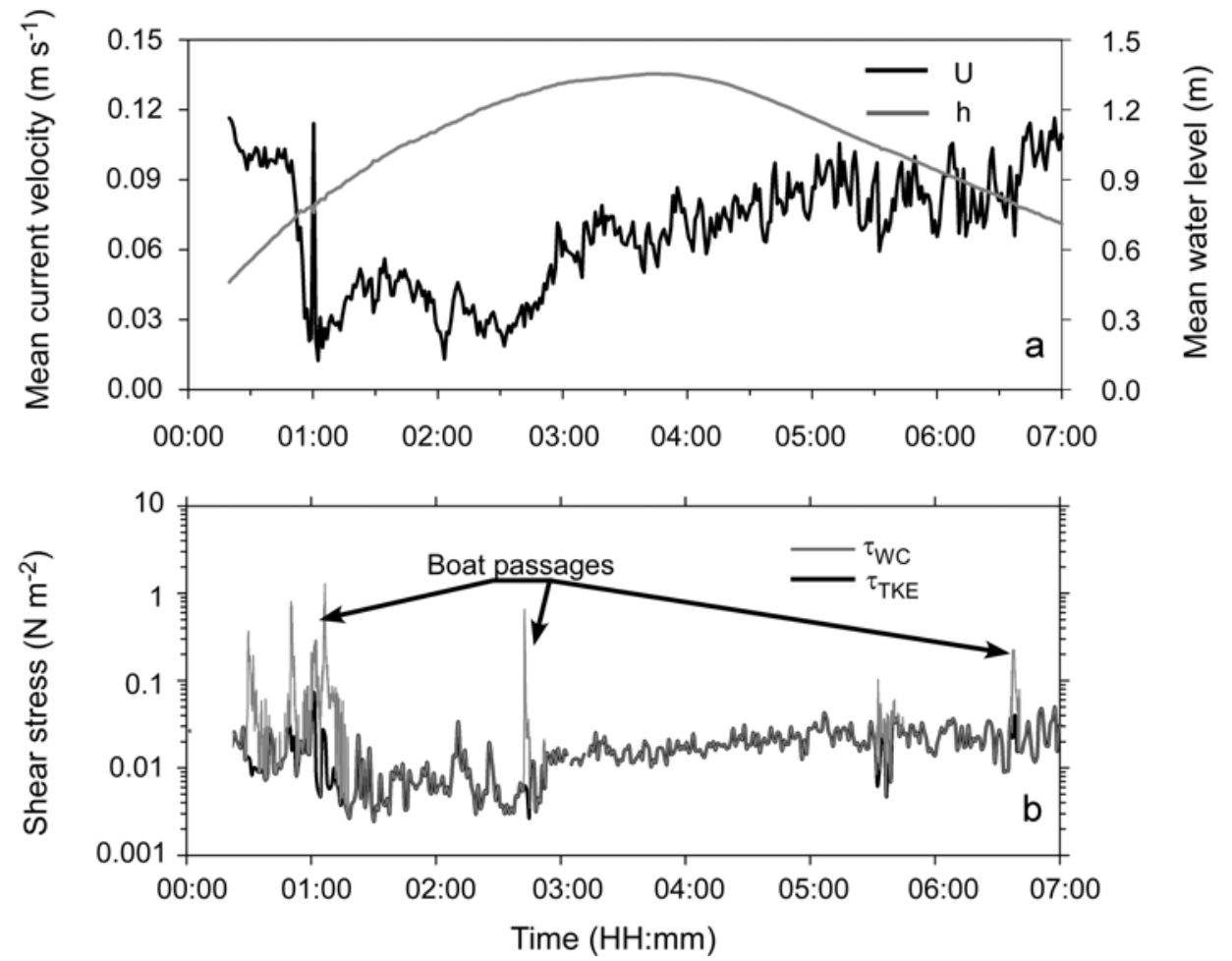
Figure 7
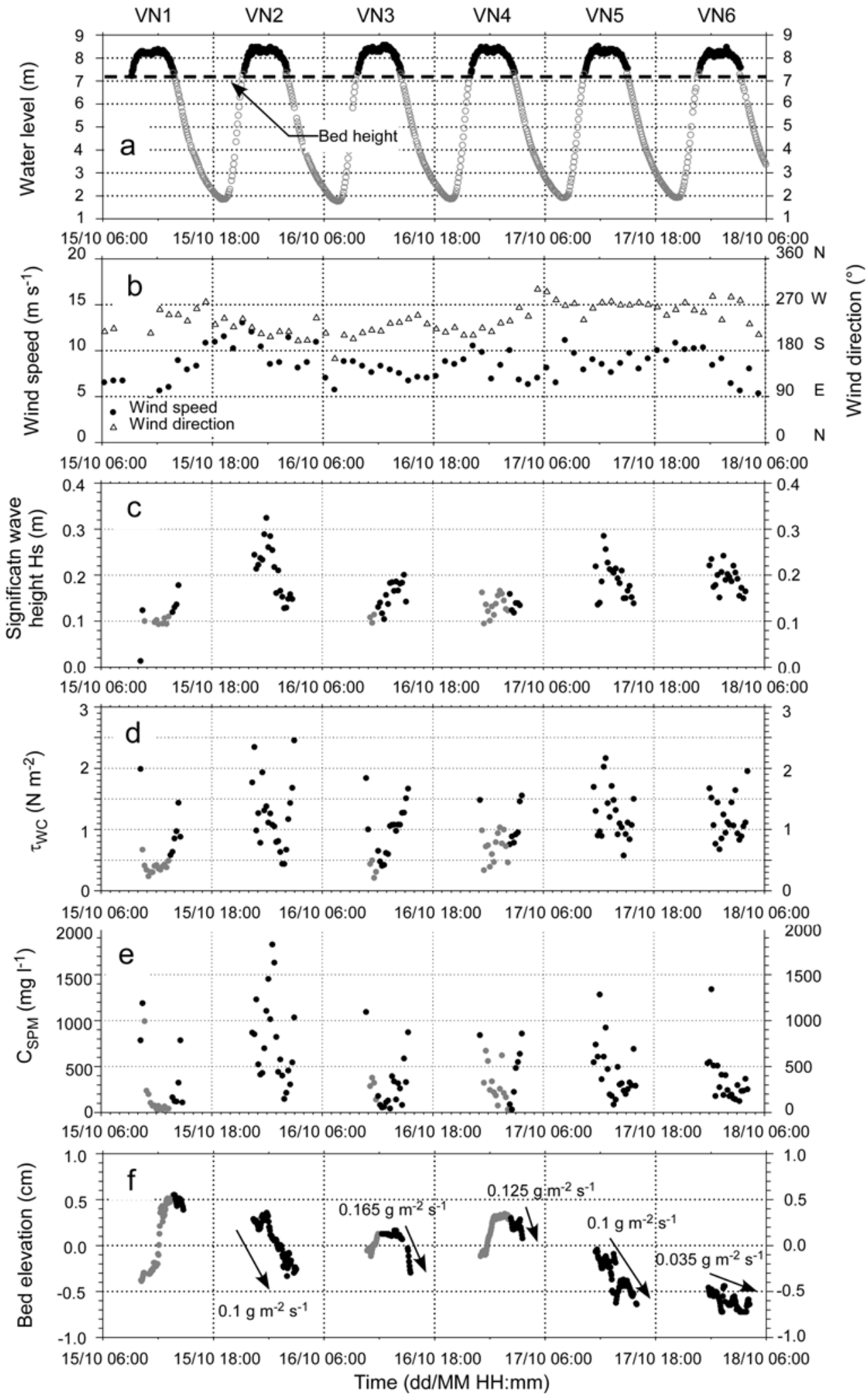
Figure 8

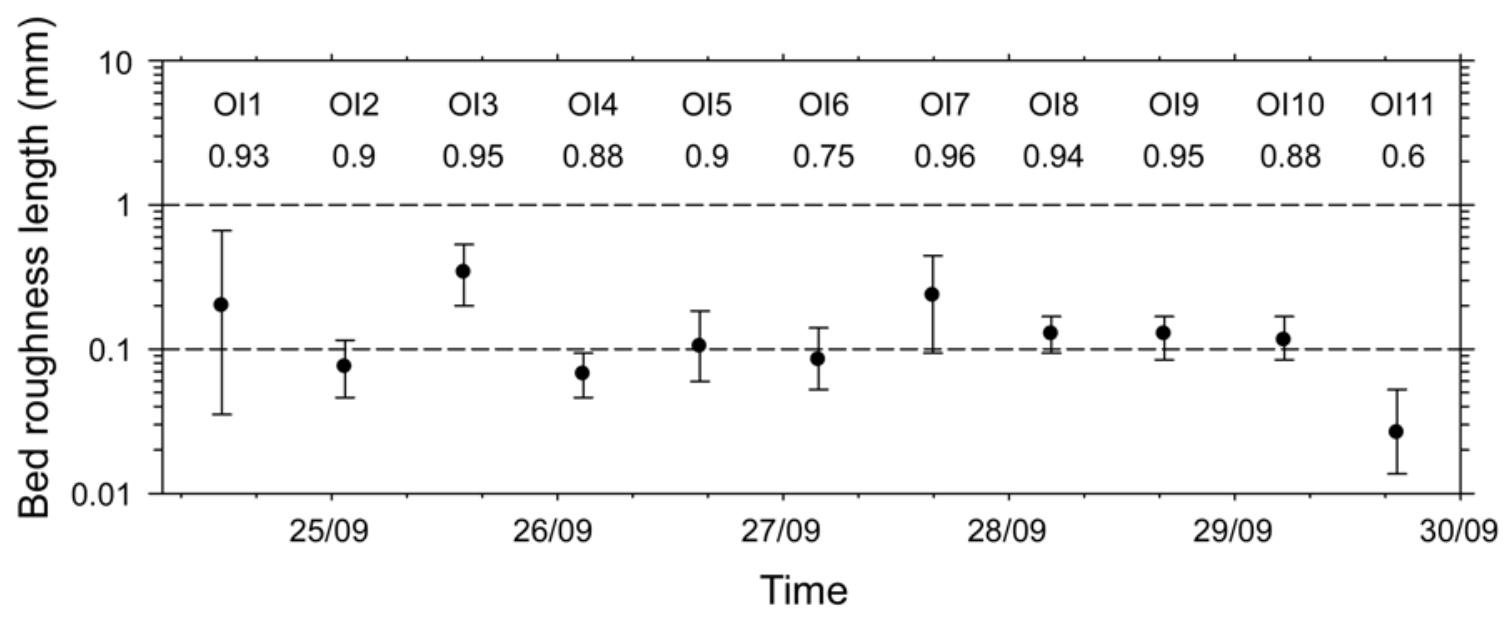


Figure 9

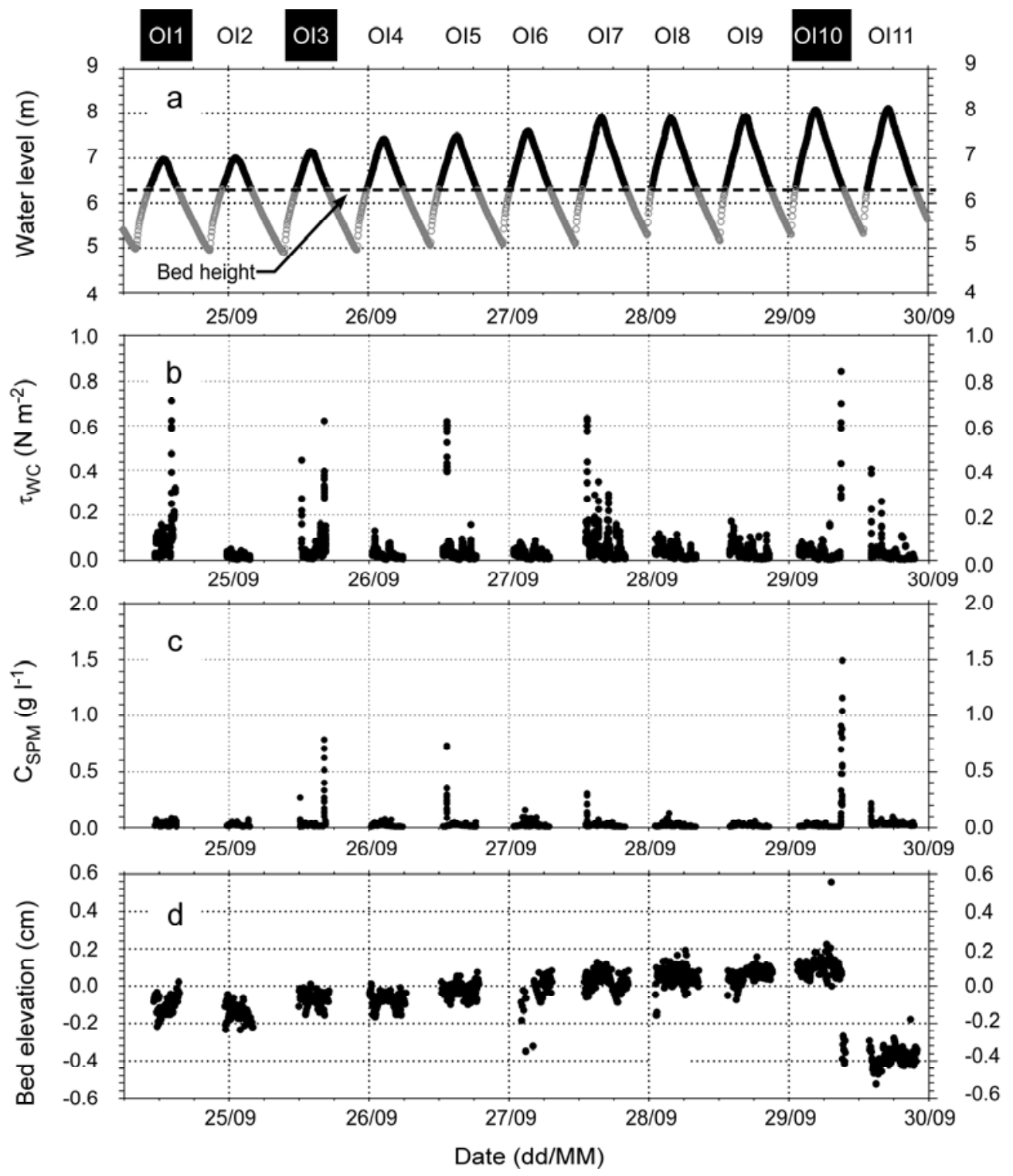


Figure 10

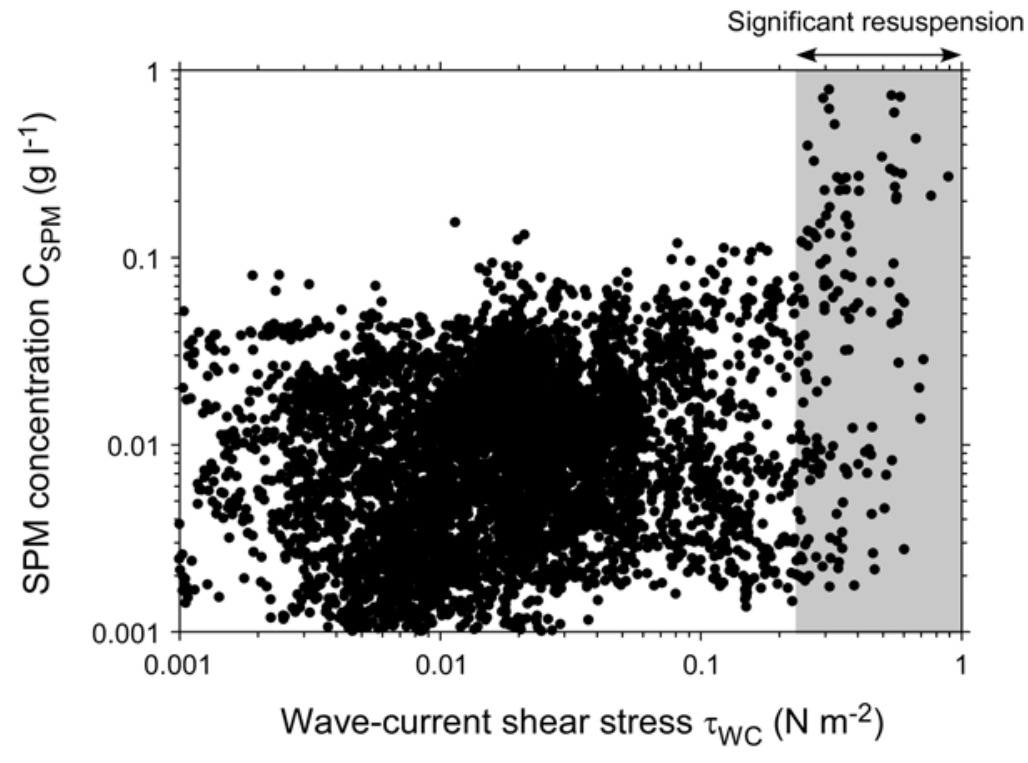

